\title{
Assessing elemental ratios as a paleotemperature proxy in the calcite shells of patelloid
}

\section{limpets}

Graniero, L.E. ${ }^{a}$, Surge, D. ${ }^{a}$, Gillikin, D.P. ${ }^{\mathrm{b}}$, Briz i Godino, I. ${ }^{\text {cde }}$, and Álvarez, M. ${ }^{\text {ce }}$

${ }^{a}$ Department of Geological Sciences, University of North Carolina Chapel Hill, 104 South Road, Chapel Hill, NC 27571-0035, USA; graniero@live.unc.edu; donna64@unc.edu

${ }^{\mathrm{b}}$ Department of Geology, Union College, 807 Union Street, Schenectady, NY 12308, USA;

gillikid@union.edu

cCONICET-Centro Austral de Investigaciones Científicas, Av./ B. Houssay, 200. Ushuaia. 9410. Argentina; ibrizgodino@gmail.com; myrianalvarez@gmail.com

${ }^{\mathrm{d}}$ Department of Archaeology, University of York, The King's Manor, York, Y01 7EP, UK.

ICSE-UNTDF, Av./ Alem, 1036 Ushuaia 9410. Argentina; ibrizgodino@ gmail.com;

myrianalvarez@gmail.com

*Corresponding author 


\begin{abstract}
Archaeological shell and fish middens are rich sources of paleoenvironmental proxy data. Patelloid limpet shells are common constituents in archaeological middens found along European, African, and South American coastlines. Paleotemperature reconstructions using oxygen isotope ratios of limpet shells depend on the ability to constrain the oxygen isotope ratio of seawater; therefore, alternative proxies are necessary for coastal localities where this is not possible. The study evaluates whether $\mathrm{Mg} / \mathrm{Ca}, \mathrm{Sr} / \mathrm{Ca}, \mathrm{Li} / \mathrm{Ca}, \mathrm{Li} / \mathrm{Mg}$, and $\mathrm{Sr} / \mathrm{Li}$ ratios are reliable proxies of sea surface temperature (SST) in the calcite layer of shells of the patelloid limpets, Patella vulgata and Nacella deaurata. We compare $\mathrm{Mg} / \mathrm{Ca}, \mathrm{Sr} / \mathrm{Ca}, \mathrm{Li} / \mathrm{Ca}, \mathrm{Li} / \mathrm{Mg}$, and $\mathrm{Sr} / \mathrm{Li}$ ratios to the seasonal variations in contemporaneous $\delta^{18} \mathrm{O}_{\text {shell }}$ values, which primarily record seasonal changes in SST. Elemental ratios $(\mathrm{Mg} / \mathrm{Ca}, \mathrm{Sr} / \mathrm{Ca}, \mathrm{Li} / \mathrm{Ca}, \mathrm{Li} / \mathrm{Mg}$, and $\mathrm{Sr} / \mathrm{Li}$ ) show no significant correlations with reconstructed SST in P. vulgata and $N$. deaurata shells, nor do they show sinusoidal cycles expected from a SST proxy. In addition, shell $\delta^{13} \mathrm{C}$ values show no significant ontogenetic trends, suggesting that these limpets exhibit little change in metabolic carbon incorporation into the shell with increasing ontogenetic age. Although shell growth rate exhibits a logarithmic decrease with age based on calculated linear extension rates, growth rate does not correlate with elemental profiles in these limpets. Overall, elemental ratios are not reliable recorders of paleotemperature in patelloid limpets.
\end{abstract}

Key words: elemental ratios, paleotemperature, patelloid limpets, oxygen isotopes, carbon isotopes, paleoceanography 


\section{Introduction}

Archaeological shell middens potentially contain archives of high-resolution seasonal variations in coastal sea surface temperature (SST). Limpet shells are common constituents in archaeological middens along European, African, and South American coastlines (Alvarez et al., 2011; Balbo et al., 2011). Oxygen isotope ratios $\left({ }^{18} \mathrm{O} /{ }^{16} \mathrm{O}\right)$ of modern and archaeological limpet shells from the genera Patella, have been used to reconstruct seasonal-scale SST and ocean circulation patterns during the Late Quaternary (Shackleton, 1973; Cohen and Tyson, 1995; Fenger et al., 2007; Ferguson et al., 2011; Colonese et al., 2012; Surge and Barrett, 2012; Wang et al., 2012). Oxygen isotope paleothermometry is based on the temperature dependence of the fractionation of biogenic carbonate and ambient waters (reviewed in Grossman, 2012). There is an inverse relationship between carbonate $\delta^{18} \mathrm{O}$ values and temperature, where increases in temperature result in a decrease in carbonate $\delta^{18} \mathrm{O}$ values. Such studies depend on the ability to constrain the $\delta^{18} \mathrm{O}$ value of seawater $\left(\delta^{18} \mathrm{O}_{\text {water }}\right)$ for accurate paleotemperature calculations. Freshwater inputs to coastal environments influence $\delta^{18} \mathrm{O}_{\text {water }}$ values making it difficult to constrain $\delta^{18} \mathrm{O}_{\text {water }}$ when freshwater inputs cannot be quantified. This is especially important in estuarine environments which are subject to seasonal variations in freshwater inputs. Alternative 
proxies, such as elemental ratios, are potentially useful for such coastal localities where traditional paleotemperature reconstruction methods, such as $\delta^{18} \mathrm{O}$ values, are unreliable.

Elemental ratios have been used as paleotemperature proxies in corals (Smith et al., 1979; de Villiers et al., 1995; Quinn et al., 2006) and foraminifera (reviewed in Baker et al., 2005) with varying degrees of success, and appear problematic in bivalves (e.g., Klein et al., 1996; Vander Putten et al., 2000; Gillikin et al., 2005; Freitas et al., 2006; Surge and Walker, 2006; Surge and Lohmann, 2008; Wisshak et al., 2008; Poulain et al., 2015). In general, factors that control elemental ratios in molluscs appear to vary among studies (e.g., Carré et al., 2006, Klein et al., 1996, Takesue and van Geen, 2004, Freitas et al., 2006; Sosidan et al., 2006; Poulain et al., 2015). For instance, some studies suggest elemental ratios such as $\mathrm{Sr} / \mathrm{Ca}$ and $\mathrm{Mg} / \mathrm{Ca}$ ratios reflect changes in growth rate (e.g., Gillikin et al., 2005; Sosidan et al., 2006; Surge and Walker, 2006; Surge and Lohmann, 2008), while others suggest a biological control (e.g., Wanamaker et al., 2008). These kinetic and metabolic controls appear to be unpredictable among different genera or even within the same species from the same locale (e.g., Lorrain et al., 2005). Therefore, further investigations on the incorporation of minor and trace element ratios in mollusk shells are warranted.

Few studies have investigated elemental ratios as an independent paleothermometer in limpet shells (Schifano and Censi, 1986; Foster and Chacko, 1995; Ferguson et al., 2011) and none to our knowledge have considered Nacella in their investigations. In addition, this is the first study 
to examine a suite of elemental ratios as paleotemperature proxies in patelloid limpets. Previous studies that investigate the $\delta^{18} \mathrm{O}-\mathrm{Mg} / \mathrm{Ca}$ relationship in Patella shells produce conflicting results. Schifano and Censi (1986) found that Patella from the Gulf of Bonagia, Sicily, exhibited different $\mathrm{Mg}$ and $\mathrm{Sr}$ relationships to temperature depending on the season. In this case, winter growth showed no correlation to temperature, in contrast with high correlation during summer $\left(\mathrm{R}^{2}=0.99\right.$; Schifano and Censi, 1986). On the other hand, Ferguson et al. (2011) concluded that $\mathrm{Mg} / \mathrm{Ca}$ ratios and $\delta^{18} \mathrm{O}$ values record the full range of SST in the Mediterranean, although shells without a clear $\delta^{18} \mathrm{O}-\mathrm{Mg} / \mathrm{Ca}$ relationship were omitted from the paleotemperature reconstruction. These seasonal breakdowns in the $\mathrm{Mg} / \mathrm{Ca}$-SST relationship have also been noted in bivalves (Vander Putten et al., 2000; Mouchi et al., 2013). Such enigmatic breakdowns in the $\delta^{18} \mathrm{O}-\mathrm{Mg} / \mathrm{Ca}$ relationship are not well understood, but may be species specific.

Although previous studies have investigated elemental ratios such as $\mathrm{Sr} / \mathrm{Ca}, \mathrm{Li} / \mathrm{Ca}, \mathrm{Li} / \mathrm{Mg}$, and $\mathrm{Sr} / \mathrm{Li}$ in calcifying organisms, there appears to be considerable variation as to how these ratios are related, if at all, to environmental conditions. For instance, $\mathrm{Sr} / \mathrm{Ca}$ profiles recorded in aragonitic shells of modern marine gastropods were found to covary with shell $\delta^{18} \mathrm{O}$ profiles (Sosidan et al., 2006; Gentry et al., 2006). Sosidan et al. (2006) established that this seasonal variation in $\mathrm{Sr} / \mathrm{Ca}$ ratios of Conus shells is due to seasonal changes in growth rate based on the covariance of $\mathrm{Sr} / \mathrm{Ca}$ ratios with $\delta^{18} \mathrm{O}$ values and linear extension rate. In inorganic calcium carbonate, we expect $\mathrm{Sr} / \mathrm{Ca}$ ratios to show a temperature dependence in aragonite due to the coprecipitation of Sr with aragonite, but not in calcite (Kinsman and Holland, 1969; Tesoriero and 
Pankow, 1996). However, in bivalves the relationship between $\mathrm{Sr} / \mathrm{Ca}$ ratios and temperature appears to be primarily related to growth rate irrespective of shell mineralogy (e.g., Purton et al., 1999; Takesue and van Geen, 2004; Gillikin et al., 2005; Lorrain et al., 2005; Poulain et al., 2015).

$\mathrm{Li} / \mathrm{Ca}$ ratios in calcite foraminifera have been investigated as a proxy for temperature, calcification rate, and carbonate ion concentration (Delaney et al., 1985; Hall and Chan, 2004; Marriott et al., 2004; Hathorne and James, 2006). Although Li/Ca ratios increase in planktonic and benthic foraminiferal tests as temperature decreases, other factors appear to be the dominant drivers of $\mathrm{Li} / \mathrm{Ca}$ ratios including microhabitat, growth rate, mineralogy, and genetic variation among species (Hall and Chan, 2004). Similarly, $\mathrm{Li} / \mathrm{Mg}$ ratios have been used to reconstruct SST in aragonitic Porites corals from the Indo-Pacific, however there is likely a biological component to the relationship as well (Hathorne et al., 2013). In bivalves the Li/Ca-SST relationship is less clear; although Li/Ca ratios showed seasonal cycles in Arctica islandica, they only exhibit a weak correlation between $\mathrm{Li} / \mathrm{Ca}$ ratios and temperature (Thébault et al., 2009). Correlations between growth increment width and river discharge suggest that fluctuations in bivalve $\mathrm{Li} / \mathrm{Ca}$ ratios may be related to calcification rate and/or riverine inputs of Li (Thébault et al., 2009; Thébault and Chauvaud 2013). Finally, Füllenbach et al. (2015) proposed Sr/Li ratios serve as a paleotemperature proxy in aragonitic bivalve shells from brackish environments; however, environments in their study are considered marine. Even so, this proxy will be investigated 
alongside the previously discussed elemental ratios to test whether $\mathrm{Sr} / \mathrm{Li}$ ratios can be applied to coastal marine environments, which may be susceptible to freshwater influence.

In summary, the present study evaluates whether $\mathrm{Mg} / \mathrm{Ca}, \mathrm{Sr} / \mathrm{Ca}, \mathrm{Li} / \mathrm{Ca}, \mathrm{Li} / \mathrm{Mg}$, and $\mathrm{Sr} / \mathrm{Li}$ ratios are reliable proxies of SST in calcite shells of the patelloid limpets, Patella vulgata and Nacella deaurata. To test this hypothesis, we compare these elemental ratios to seasonal variations in contemporaneous $\delta^{18} \mathrm{O}_{\text {shell }}$ values, which primarily record seasonal changes in SST.

\section{Materials and Methods}

\subsection{Shell and Water Samples}

Patella vulgata were collected alive from the rocky intertidal zone in Whitley Bay, Northumberland, England in June 2001 (Figure 1A; specimen NL-0601-3 from Fenger et al., 2007) and in Rack Wick Bay, Westray, Orkney, Scotland in August 2009 (specimen ORK-LT5) (Table 1, Figure 1A). Periodic measurements made in previous studies indicate that these locations have normal marine salinity, ranging from 34.0 to 34.8 in Whitley Bay (Fenger et al., 2007; Surge and Barrett, 2012).

Modern N. deaurata were collected from the lower intertidal zone of the Beagle Channel (the Outer Cambaceres Bay identified as CE in Figure 1 of Colonese et al., 2012), Tierra del Fuego, Argentina in August 2009 (specimens ND-MOD-1 and ND-MOD-6; Table 1, Figure 1B). The Beagle Channel is semi-enclosed and has restricted exchange with Pacific waters (Antezana, 
1999). It is influenced by river discharge and summer meltwater (Gordillo et al., 2008; Colonese et al., 2012). The monthly average temperature and salinity from 2009 to 2010 are $7.0 \pm 1.6^{\circ} \mathrm{C}$ and 34.4 \pm 1.8 psu, respectively, in Outer Cambares Bay (Colonese et al., 2012), similar to ongoing monthly monitoring in the Beagle Channel (beginning in October 2015) that indicates that the range in temperature is $10.1 \pm 2.4^{\circ} \mathrm{C}$ and the range in salinity is $30.6 \pm 0.8 \mathrm{psu}$. Two archaeological $N$. deaurata shells (between 1155 $\underline{4}$ 40BP (CNA 1056) and 1385+25BP (CNA 590) Evans et al., 2016) were selected from the previously excavated Lanashuaia II site (Colonese et al., 2012) (specimens ND-ARCH-1 and ND-ARCH-3). We refer the reader to Fenger et al. (2007) and Colonese et al. (2012) for more information about the ecology of these two species.

Waters samples from the shore of Outer Cambacares Bay (Beagle Channel, 54 $52^{\prime} 49.62^{\prime \prime S}$ $\left.67^{\circ} 16^{\prime} 26.49^{\prime \prime} \mathrm{W}\right)$ were collected once a month to characterize the seasonal variation in oxygen isotope ratios. Monthly sample collection began in October 2015 and will continue for an entire year. We report our water analyses to date (October 2015 to March 2016) together with previously published $\delta^{18} \mathrm{O}_{\text {water }}$ values from Colonese et al. (2012). Water was collected and tightly sealed in $30 \mathrm{ml}$ glass vials. Water $\delta^{18} \mathrm{O}$ were measured on a gas-source isotope ratio mass spectrometer (Finnigan Delta S) at the University of Arizona. Samples were equilibrated with $\mathrm{CO}_{2}$ gas at approximately $15^{\circ} \mathrm{C}$ in an automated equilibration device coupled to the mass spectrometer. Standardization is based on international reference materials VSMOW and SLAP. Precision is $0.08 \%$ or better for $\delta^{18} \mathrm{O}$ based on replicates of internal standards. 


\subsection{Preparation of shell cross sections}

Shells were sectioned from anterior to posterior using a Gryphon diamond band saw (Figure 2A). Each half of the sectioned shells were mounted on separate microscope slides and cut into thick sections using a Buehler Isomet low-speed saw. Both thick sections were ground and polished with $1 \mu \mathrm{m}$ diamond suspension grit (Buehler). One polished thick section was used for isotopic and elemental analyses ( $3 \mathrm{~mm}$ thick) and the other was used to make acetate peels $(0.5 \mathrm{~mm}$ thick). Acetate peels were prepared by etching the shell surface with $5 \% \mathrm{HCl}$ solution for 30 seconds. After etching the surface, shells were drenched in acetone, then carefully covered with a $76.2 \mu \mathrm{m}(0.003 \mathrm{inch})$ thick acetate sheet for 45 minutes. Acetate peels were used to enhance the visibility of growth lines (Figure 2B). Growth increments were used to guide isotopic sampling.

\subsection{Stable Isotopic Analysis $\left(\delta^{18} \mathrm{O}\right.$ and $\left.\delta^{13} \mathrm{C}\right)$}

Samples for isotopic analysis were micromilled at submonthly resolution guided by prominent growth increments using a computerized Merchantek micromill. $P$. vulgata shells are comprised of seven shell layers of both calcitic and aragonitic mineralogy (see Fenger et al., 2007 for details). Carbonate microsamples were collected from the inner calcitic layer of Patella and Nacella specimens (i.e., layer m+2; Fenger et al., 2007; Ferguson et al., 2011; Colonese et al., 2012). Shell NL 0601-3 was previously analyzed by Fenger et al. (2007). All other isotope samples were analyzed using a Kiel III coupled to a Finnigan MAT 252 gas-ratio mass spectrometer at the University of Arizona. Analytical precision is $0.08 \%$ or $\delta^{13} \mathrm{C}$ and $0.10 \%$ for $\delta^{18} \mathrm{O}$. Isotopic ratios are reported relative to the Vienna-Pee Dee Belemnite (VPDB) standard. 
Sea surface temperature reconstructions were calculated using the following paleotemperature equation for calcite (Friedman and O’Neil, 1977 modified from Tarutani et al, 1969):

$$
\begin{gathered}
1000 \ln \alpha=\left(2.78 \times 10^{6}\right) / \mathrm{T}^{2}-2.89 \\
\alpha_{\text {shell-water }}=\left(\delta^{18} \mathrm{O}_{\text {shell }}+1000\right) /\left(\delta^{18} \mathrm{O}_{\text {water }}+1000\right)
\end{gathered}
$$

where $\alpha$ is the fractionation factor between shell carbonate and water, $\mathrm{T}$ is temperature $\left({ }^{\circ} \mathrm{C}\right)$, $\delta^{18} \mathrm{O}_{\text {water }}$ is the oxygen isotope ratio of ambient water versus Vienna-Standard Mean Ocean Water (VSMOW). The annual average $\delta^{18} \mathrm{O}_{\text {water }}$ values for Newcastle and Orkney, UK are $0.10 \pm 0.04 \%$ for the North Sea (Hickson et al., 1999) and $0.31 \pm 0.17 \%$ for Rack Wick Bay (Surge and Barrett, 2012), respectively. Both locations are fully marine and are not significantly influenced by freshwater runoff (Fenger et al., 2007; Surge and Barrett, 2012 and references therein). The $\delta^{18} \mathrm{O}_{\text {water }}$ value for the Beagle Channel (Outer Cambaceres Bay identified as CE in Fig. 1 of Colonese et al., 2012), Tierra del Fuego, Argentina is $-1.3 \pm 0.2 \%$ based on an average of monthly measurements taken from December 2009 to October 2010 by Colonese et al. (2012) and October 2015 to March 2016 from this study (Table 2). Gordillo et al. (2015) also suggest $\delta^{18} \mathrm{O}_{\text {water }}$ values at this site are relatively constant and that is appropriate to assume a constant $\delta^{18} \mathrm{O}_{\text {water }}$ value for paleotemperature reconstruction. It is unlikely that the archaeological Nacella shells came from Inner Cambaceres Bay, given that modern day Nacella of this size are not present in the Inner Cambaceres Bay and are harvested primarily from the Outer Bay for human consumption (Briz i Godino, pers. comm.). Nacella prefer to inhabit environments with a high level of wave movement, which does not describe conditions in the Inner Cambaceres Bay 
(Briz i Godino, pers. comm.). Patella shell $\delta^{18} \mathrm{O}$ values were corrected for the $+1.01 \%$ predictable offset observed by Fenger et al. (2007). Colonese et al. (2012) found that Nacella precipitate their shells in isotopic equilibrium requiring no correction factor to be applied.

\subsection{Analysis of elemental ratios by LA-ICP-MS}

High-resolution elemental analyses were conducted using a laser-ablation inductively-coupled mass spectrometer (LA-ICP-MS; CETAC LSX-213 frequency quintupled Nd:YAG laser ( $\lambda=$ $213 \mathrm{~nm}$ ) coupled to a Perkin Elmer Elan 6100 DRC ICP- MS) in the Geology Department at Union College, NY (Table 3). Instrumental parameters and data reduction are discussed in Gillikin and Dehairs (2013) and O'Neil and Gillikin (2014). Spot analyses were completed (50 $\mu \mathrm{m}$ diameter) at constant spacing ( 150 or $300 \mu \mathrm{m}$ ). ThO/Th ratios were monitored daily to check for oxide formation and were always less than $0.6 \%$ (monitored using the NIST 612 glass

standard). ${ }^{43} \mathrm{Ca}$ was used as an internal standard and ${ }^{7} \mathrm{Li},{ }^{26} \mathrm{Mg}$, and ${ }^{86} \mathrm{Sr}$ were monitored. Data were calibrated using the silicate standard NIST612 with values from Pearce et al. (1997). Analysis of the U.S. Geological Survey pressed carbonate pellet MACS3 suggested a robust calibration and small error (percent relative standard deviations on 26 analyses over three analytical days are: $\mathrm{Li}=5.6 \%, \mathrm{Mg}=4.6 \%$, and $\mathrm{Sr}=3.2 \%$ ). The laser was shot in the inner calcitic layer of Patella specimens (i.e., m+2; Fenger et al., 2007) and in the inner calcitic layer of Nacella specimens.

\section{Results}




\subsection{Shell $\delta^{18} \mathrm{O}$ and $\delta^{13} \mathrm{C}$ values}

Live-collected Patella and Nacella shells exhibit a quasi-sinusoidal trend in the temporal variation of $\delta^{18} \mathrm{O}$ values (Figures $3 \mathrm{~A}, \mathrm{C}, \mathrm{E}$ and $\mathrm{F}$ ). Their number of cycles (peak to peak or trough to trough) range from about 2.5 (ND-MOD-6, between 0-7.5 mm) to 6.5 (NL-0601-3, between 0-10.7 mm). In contrast, the oxygen isotope time series recorded in archaeological shell ND-ARCH-1 shows an incomplete cycle (between 0-5.5 mm), and specimen ND-ARCH-3 contains only one complete cycle (between 0-8.25 mm). Since temperature fluctuates seasonally, these shell $\delta^{18} \mathrm{O}$ minima and maxima are used as measures of annual cycles. Assuming one cycle is equivalent to one year of growth as found in other limpet shells (Fenger et al., 2007; Surge et al., 2013), the ontogenetic age for modern specimens range from $~ 2.5-6.5$ years, whereas the two archaeological shells are half a year to a year old. Table 1 summarizes the estimated age and descriptive statistics of the $\delta^{18} \mathrm{O}$ and $\delta^{13} \mathrm{C}$ time series for each individual. Values of $\delta^{18} \mathrm{O}$ and $\delta^{13} \mathrm{C}$ do not covary except in the last $\sim 3$ years of life of specimen NL-0601-3. There is no consistent ontogenetic trend in $\delta^{13} \mathrm{C}$ values among specimens analyzed in this study (Figure 4).

\subsection{Linear extension rates}

Mean annual linear extension rates (LER) were calculated based on $\delta^{18} \mathrm{O}_{\text {shell }}$ minima and maxima, which represent summer and winter temperatures, respectively. Mean annual LER were

calculated by estimating the number of years represented by the $\delta^{18} \mathrm{O}_{\text {shell }}$ profile and measuring the distance along the shell. Mean LER over the lifetime of the limpets were lower in the UK (1.8 and $2.6 \mathrm{~mm} / \mathrm{yr}$ ), than in Argentina (3.0 to $11.0 \mathrm{~mm} / \mathrm{yr}$; Table 1). Furthermore, 
archaeological specimens have growth LER that are roughly 2-4 times higher than live-collected specimens of the same species at the same location. In shells where several years were sampled, mean annual LER show a logarithmic trend that decreases with ontogenetic age, although only one Patella (NL 0601-3) shows a statistically significant trend $(\mathrm{P} \leq 0.05)$ (Figure 5).

\subsection{Elemental ratios}

Unlike oxygen isotope ratios, there does not appear to be regular annual cycles in any studied profiles of elemental ratios (Figures 6-10). Similar to carbon isotope ratios, no ontogenetic trends are evident in any of the profiles of elemental ratios. In general, observe some cyclicity in Patella $\mathrm{Mg} / \mathrm{Ca}$ profiles (Figure 6E, F) and more flat lying trends in Nacella $\mathrm{Mg} / \mathrm{Ca}$ profiles (Figure 6A, B, D). Mg/Ca ratios in $P$. vulgata exhibit an apparent cyclicity, although these cycles do not correspond to a coeval $\delta^{18} \mathrm{O}$ cycle and vary more than two-fold in the Northumberland shell (Figure 6E). The Sr/Ca ratios exhibit cyclicity in some shells (Figure 7C, F) and not others (Figure 7A, E). When cyclicity is evident in $\mathrm{Sr} / \mathrm{Ca}$ there is no associated relationship with cooccurring shell $\delta^{18} \mathrm{O}$ values. The $\mathrm{Li} / \mathrm{Ca}$ ratios were similar for all specimens ranging from $\sim 0.02$ to $0.06 \mathrm{mmol} / \mathrm{mol}$, with the values fluctuating more rapidly than the $\delta^{18} \mathrm{O}$ values (Figure 8 ). $\mathrm{Sr} / \mathrm{Li}$ ratios do not correspond with $\delta^{18} \mathrm{O}$ curves and tend to be more flat laying than $\delta^{18} \mathrm{O}$ profiles (Figure 9). Li/Mg ratios appear to exhibit distinct cycles in ND MOD-6, ND MOD-1, and NDARCH-3, although these cycles do not correspond to a coeval $\delta^{18} \mathrm{O}$ cycle (Figure $\left.10 \mathrm{~A}, \mathrm{C}, \mathrm{D}\right)$.

\subsection{Elemental ratio-SST relationship}


To evaluate elemental ratio-SST correlations, reconstructed SST values were calculated using an established paleotemperature equation (Equations 1 and 2 above). Elemental ratios (Mg/Ca, $\mathrm{Sr} / \mathrm{Ca}, \mathrm{Li} / \mathrm{Ca}, \mathrm{Sr} / \mathrm{Li}, \mathrm{Li} / \mathrm{Mg}$ ) show no apparent relationship with reconstructed $\mathrm{SST}$ in $P$. vulgata (Figure 11) and N. deaurata (Figure 12) shells. Rather, the cross plots exhibit either a shotgun pattern or relatively flat trend. Nacella deaurata shells have lower $\mathrm{Mg} / \mathrm{Ca}$ ratios $(<10 \mathrm{mmol} / \mathrm{mol})$ than $P$. vulgata $(>10 \mathrm{mmol} / \mathrm{mol}) . \mathrm{Sr} / \mathrm{Ca}$ ratios are relatively flat lying, and the range for all specimens is approximately 1 to $2 \mathrm{mmol} / \mathrm{mol}$ (Figure 11,12 ). $\mathrm{Li} / \mathrm{Ca}$ and $\mathrm{Li} / \mathrm{Mg}$ ratios have large scatter in the data for both species (Figure 11B, 11E, 12B, 12E). Nacella deaurata shells have $\mathrm{Li} / \mathrm{Mg}$ ratios an order of magnitude higher than $P$. vulgata shells (Figure 10).

\section{Discussion}

There are no apparent elemental ratio-SST trends in shells of $P$. vulgata and $N$. deaurata, therefore $\mathrm{Mg} / \mathrm{Ca}, \mathrm{Sr} / \mathrm{Ca}, \mathrm{Li} / \mathrm{Ca}, \mathrm{Sr} / \mathrm{Li}$, and $\mathrm{Li} / \mathrm{Mg}$ are not reliable recorders of SST in paleoenvironmental studies (Figure 11 and Figure 12, respectively). At Blythe, UK, approximately $20 \mathrm{~km}$ from Newcastle, average annual SST trends exhibit a clear sinusoidal trend ranging from about $5^{\circ} \mathrm{C}$ in February to $14^{\circ} \mathrm{C}$ in August (Figure 13A). In the Beagle Channel, compiled SST from 1963 through 2011 show a distinct, consistent sinusoidal trend ranging from about $5{ }^{\circ} \mathrm{C}$ in July/August to $10{ }^{\circ} \mathrm{C}$ in January (Figure 13B). At both sites, shell $\delta^{18} \mathrm{O}$ values reflect this distinct sinusoidal trend (e.g., Figure 3), especially in specimens older than 1.5 years. Based on the paleotemperature equation (Equations 1,2), these temperature ranges account for a roughly $2 \%$ range in shell $\delta^{18} \mathrm{O}$ values at Newcastle and a $1 \%$ range in the Beagle Channel. A 
compilation of monthly $\delta^{18} \mathrm{O}_{\text {water }}$ data from Tierra del Fuego indicates that variability in $\delta^{18} \mathrm{O}_{\text {water }}$ values is minimal $(0.2 \%$; Table 2$)$. Therefore, shell $\delta^{18} \mathrm{O}$ values are most strongly driven by variations in SST. The annual cyclicity in shell $\delta^{18} \mathrm{O}$ values is mainly driven by temperature, therefore, it is reasonable to compare elemental ratios to shell $\delta^{18} \mathrm{O}$ values to evaluate whether elemental ratios record variations in temperature (Figure 11, 12). Thus, it is clear that the elemental ratios do not follow the expected sinusoidal variation in SST. Furthermore, salinity variations are not likely to influence $\mathrm{Mg}, \mathrm{Sr}$, and $\mathrm{Ca}$ concentrations in the water because $\mathrm{Mg} / \mathrm{Ca}$ and $\mathrm{Sr} / \mathrm{Ca}$ are conservative at salinities above 10 psu (Dodd and Crisp, 1982; Lazareth et al., 2003). Since study sites are fully marine, salinity variations are not expected to significantly affect the $\mathrm{Mg} / \mathrm{Ca}$ and/or $\mathrm{Sr} / \mathrm{Ca}$ at either site.

Patella vulgata from this study do not show the significant $\mathrm{Mg} / \mathrm{Ca}-\mathrm{SST}$ correlation observed in P. caerulea (Schifano and Censi, 1986; Ferguson et al., 2011) and P. rustica (Ferguson et al., 2011) from previous studies. For instance, Ferguson et al. (2011) were able to reconstruct SST within $\sim 4^{\circ} \mathrm{C}$ using $\mathrm{Mg} / \mathrm{Ca}$ ratios in $P$. caerulea and $P$. rustica from the Mediterranean Sea, although they did report some inconsistencies in the $\mathrm{Mg} / \mathrm{Ca}$-SST relationship. Shells with no clear correlation between $\delta^{18} \mathrm{O}$ and $\mathrm{Mg} / \mathrm{Ca}$ values were excluded from their SST reconstruction, suggesting that $\mathrm{Mg} / \mathrm{Ca}$ ratios are unpredictable as a paleotemperature proxy. While the absolute $\mathrm{Mg} / \mathrm{Ca}$ ratios measured in this study are comparable to those from Ferguson et al. (2011) (about 11 to $30 \mathrm{mmol} / \mathrm{mol}$ ), our samples exhibit the enigmatic breakdown of this $\mathrm{Mg} / \mathrm{Ca}-\mathrm{SST}$ relationship that was observed in one shell from the aforementioned study. 
While the cause of this breakdown in Mg/Ca-SST in limpet shells is unknown, we consider habitat heterogeneity and changes in life habit as potential causes. Differences in growth patterns between studies may explain this disparity between $P$. vulgata from the UK, which grow slowly during winter and rapidly during early summer (Blackmore, 1969; Baxter, 1982; Fenger et al., 2007), and other Patella from the Mediterranean, which grow slowly during the summer (Schifano and Censi, 1986). Variations in microhabitat may potentially impact elemental ratios in limpets as well. A previous study found that $P$. vulgata living in sheltered versus exposed shores are exposed to differing food supply, grazing activity, dessication stress, and predation (Jenkins and Hartnoll, 2001). For instance, grazing at sheltered shores is less than 50\% of that at exposed shores, although the cause of this dissimilarity is debated (see Jenkins and Hartnoll 2001). Nevertheless, Jenkins and Hartnoll (2001) showed that limpets at comparable densities from sheltered and exposed shores exhibit no significant difference in growth rate despite occupying disparate habitats. More broadly, the difference between limpets inhabiting subtidal and intertidal environments may influence the incorporation of trace elements into shells. Limpets living in subtidal environments experience constant submersion and higher food availability than those from intertidal environments (Wilmer, 2005). The Mg/Ca-SST relationship appears to differ between subtidal P. caerulea (Schifano and Censi, 1986), intertidal P. rustica, P. caerulea (Ferguson et al., 2011), and P. vulgata from this study. Furthermore, Schifano and Censi (1986) found that the $\mathrm{Mg} / \mathrm{Ca}-\mathrm{SST}$ in Patella changes seasonally, showing a 
stronger correlation $\left(\mathrm{R}^{2}=0.99\right)$ during warm temperatures, although the annual correlation is significant as well $\left(\mathrm{R}^{2}=0.82\right)$.

Strontium to calcium ratios are variable among individuals that grew at the same location, therefore, we suggest that $\mathrm{Sr} / \mathrm{Ca}$ ratios in our specimens are do not appear to be governed by environmental controls. Previous studies reasoned that shell $\mathrm{Sr} / \mathrm{Ca}$ ratios may be related to calcification temperature (Dodd, 1965), kinetic effects (e.g., Carpenter and Lohmann, 1992, Lorens, 1981), biological processes, and/or salinity (see Lorrain et al., 2005 for a review). However, due to the lack of Sr/Ca-SST correlation (Figure 11, 12) and no apparent ontogenetic trends (Figure 7), temperature and metabolism do not appear to be controlling the $\mathrm{Sr} / \mathrm{Ca}$ ratios in $N$. deaurata and $P$. vulgata. Unfortunately, the mechanism of $\mathrm{Sr}^{2+}$ incorporation into the shell is still not well understood and is likely controlled by multiple mechanisms. It is likely that $\mathrm{Sr} / \mathrm{Ca}$ ratios are primarily under biological control, although further research is needed to assess how biology affects the process of $\mathrm{Sr}^{2+}$ incorporation from the water column, through the body, and ultimately into the shell (Gillikin et al., 2005). When the Sr/Ca partition coefficient deviates significantly from 1, Gillikin et al. (2005) suggest controls on Sr/Ca ratios within the shell are controlled by biological processes. The analysis of water $\mathrm{Sr} / \mathrm{Ca}$ ratios may shed light on the degree of biological controls on shell $\mathrm{Sr} / \mathrm{Ca}$ ratios.

Recently, $\mathrm{Li}^{+}$has gained attention as an element that may be a useful paleotemperature proxy in biological carbonates (Delaney et al., 1985; Hall and Chan, 2004; Marriott et al., 2004; Hathorne 
and James, 2006; Thébault et al., 2009; Thébault and Chauvaud, 2013). The Li/Ca ratios from this study are comparable to values reported for Pecten maximus ranging from $\sim 0.01$ to 0.100 mmol/mol (Thébault and Chauvaud, 2013). Modern and archaeological Li/Ca ratios in $N$. deaurata from Tierra del Fuego are comparable, generally ranging from 0.03 to $0.06 \mathrm{mmol} / \mathrm{mol}$ (Figure 8A-D). Likewise, inter-individual variation was low in P. vulgata from the UK. This finding suggests that shell Li/Ca ratios are under environmental control; however, seasonal fluctuations in shell Li/Ca ratios are difficult to distinguish (Figure 8). While previous studies suggest that higher SST increases the amount of $\mathrm{Li}^{+}$incorporated into Cerastoderma edule (Füllenbach et al., 2015), there is no evidence of this effect in $N$. deaurata or P. vulgata. For $P$. vulgata, there is a decrease in Li/Ca with ontogeny in ORK LT5 $\left(\mathrm{R}^{2}=0.68\right)$ and NL 0601-3 $\left(\mathrm{R}^{2}=0.31\right)$. Therefore, changes in metabolism and/or growth rate with ontogeny may be influencing $\mathrm{Li}^{+}$incorporation into the shell.

Archaeological and modern $N$. deaurata shells show similar elemental ratio-SST relationships (Figure 12). This may suggest that while the controls on limpet shell elemental ratios $(\mathrm{Mg} / \mathrm{Ca}$, $\mathrm{Sr} / \mathrm{Ca}, \mathrm{Li} / \mathrm{Ca}, \mathrm{Sr} / \mathrm{Li}, \mathrm{Li} / \mathrm{Mg}$ ) are not temperature-dependent, they likely have not changed significantly over time.

\section{Conclusion}

Elemental ratios (e.g., $\mathrm{Mg} / \mathrm{Ca}, \mathrm{Sr} / \mathrm{Ca}, \mathrm{Li} / \mathrm{Ca}, \mathrm{Sr} / \mathrm{Li}, \mathrm{Li} / \mathrm{Mg}$ ) are not reliable recorders of paleotemperature in patelloid limpets. Although our results exhibit the breakdown in the $\mathrm{Mg} / \mathrm{Ca}-$ 
SST relationship presented by Ferguson et al. (2011), they are consistent with the assessment made by Foster and Chacko (1995) that the incorporation of Mg in Patella vulgata are insensitive to changes in environmental conditions. While the cause of enigmatic breakdowns in $\mathrm{Mg} / \mathrm{Ca}-\mathrm{SST}$ in limpet shells is unknown, it may be the result of localized differences in habitat between limpets.

$\mathrm{Sr} / \mathrm{Ca}$ ratios varied among individuals growing at the same location, which suggests that $\mathrm{Sr} / \mathrm{Ca}$ ratios are not likely dominated by environmental controls. The lack of Sr/Ca-SST correlation and no apparent ontogenetic trends suggest that temperature and metabolism do not appear to be controlling the $\mathrm{Sr} / \mathrm{Ca}$ ratios in $N$. deaurata and $P$. vulgata. Conversely, inter-individual variations in $\mathrm{Li} / \mathrm{Ca}$ were low in $P$. vulgata from the $\mathrm{UK}$ suggesting that shell $\mathrm{Li} / \mathrm{Ca}$ ratios may be under environmental control, although they lack clear seasonal fluctuations in shell Li/Ca ratios as would be expected for a SST proxy (Figure 8). For P. vulgata, there is a decrease in Li/Ca with ontogeny in both ORK LT5 $\left(\mathrm{R}^{2}=0.68\right)$ and NL 0601-3 $\left(\mathrm{R}^{2}=0.31\right)$. Therefore, changes in metabolism and/or growth rate may influence $\mathrm{Li}^{+}$incorporation into the shell. Further research is necessary to establish the controls on elemental ratios in limpet shells.

Considering the variability in elemental profiles between individuals growing in the same location and the lack of any ontogenic trends or any other discernable trends, we suggest that elemental incorporation into limpet shells are governed by a plethora of factors resulting in large inter-individual differences. However, we were able to rule out growth-rate and other ontogenic 
effects as have been observed in bivalves (e.g., Purton et al., 1999; Gillikin et al., 2005; Lorrain et al., 2005). Similar to bivalves (Poulain et al., 2015), limpet shell elemental ratios seem to be under strong physiological control.

\section{Acknowledgements}

We thank the United States National Science Foundation (NSF) for funding this project (AGS1103371; awarded to DS), as well as Union College's LA-ICP-MS (NSF-CCLI \#9952410 and NSF-MRI \#1039832). We also thank Matthew Manon for general maintenance of the LA-ICPMS instrumentation. Thanks to David Dettman at the Environmental Isotope Laboratory, University of Arizona, for performing stable isotope analyses. Thanks to Dr. G. Lovrich and his team (CONICE-CADIC) for their help in the measurement of marine water values in Tierra del Fuego. Funding for the project about Fuegian shell middens was provided by the Ministerio de Ciencia e Innovación-Spain (project: HAR2009-06996), Consejo Nacional de Investigaciones Científicas y Técnicas-Argentina (project: PIP-0706) and the Wenner-Gren Foundation for Anthropological Research-United States (project: GR7846). The comments and suggestions of the anonymous reviewers significantly improved the quality of the manuscript. 


\section{References}

Álvarez, M., Briz i Godino, I., Balbo, A., Madella, M., 2011. Shell middens as archives of past environments, human dispersal and specialized resource management. Quat. Int. 239, 1-7.

Antezana, T., 1999. Hydrographic features of Magellan and Fuegian inland passages and adjacent Subantarctic waters. Sci. Mar. 63(S1), 23-34.

Balbo, A., Madella, M., Briz i Godino, I., Álvarez, M., 2011. Shell midden research: An interdisciplinary agenda for the Quaternary and Social Sciences. Quat. Int. 239(1-2), 147152.

Baxter, J.M., 1982. Population dynamics of Patella vulgata in Orkney. Neth. J. of Sea Res. 16, 96-104.

Blackmore, D.T., 1969. Studies of Patella vulgata L.I. Growth, reproduction and zonal distribution. J. Exp. Mar. Biol. Ecol. 3(2), 200-213.Carpenter, S. J., \& Lohmann, K. C. (1992). Sr/Mg ratios of modern calcite: empirical indicators of ocean chemistry and precipitation rate .Geochim. Cosmochim. Acta 56, 1837-1849.

Carré, M., Bentaleb, I., Bruguier, O., Ordinola, E., Barrett, N.T., Fontugne, M., 2006. Calcification rate influence on trace element concentrations in aragonitic bivalve shells: Evidences and mechanisms. Geochim. Cosmochim. Ac. 70(19), 4906-4920.

Cohen, A.L., and Tyson, P.D., 1995. Sea-surface temperature fluctuations off southern Africa. The Holocene, 5(3): 304-312.

Colonese, A.C., Verdún-Castelló, E., Álvarez, M., Briz i Godino, I., Zurro, D., Salvatelli, L., 2012. Oxygen isotopic composition of limpet shells from the Beagle Channel: 
implications for seasonal studies in shell middens of Tierra del Fuego. J. Archaeol. Sci. 39, 1738-1748.

Delaney, M.L., Bé, A.W.H., Boyle, E.A., 1985. Li, Sr, Mg, and Na in foraminiferal calcite shells from laboratory culture, sediment traps, and sediment cores. Geochim. Cosmochim. Acta 49(6), 1327-1341.

de Villers, S., Nelson, B.K., and Chivas, A.R., 1995. Biological controls on coral Sr/Ca and d18O reconstruction of sea surface temperatures. Science 269(5228), 1247-1249.

Dodd, J. R., 1965. Environmental control of strontium and magnesium in Mytilus. Geochim. Cosmochim. Acta, 29: 385--398.

Dodd, J.R. and Crisp, E.L., 1982. Non-linear variation with salinity of $\mathrm{Sr} / \mathrm{Ca}$ and $\mathrm{Mg} / \mathrm{Ca}$ ratios in water and aragonitic bivalve shells and implications for paleosalinity studies. Palaeogeogr., Palaeoclimatol., Palaeoecol., 38: 45-56.

Evans, S., Briz, I., Álvarez, M., Roswell, K., Collier, P., Prosser, R.N.., Mulville, J., Lacrouts, A., Collins, M. and Speller, C., 2016. Using combined biomolecular methods to explore whale exploitation and social aggregation in hunter-gatherer-fisher society in Tierra del Fuego . J. of Arch. Scie.: Rep. 6, 757-767. Fenger, T., Surge, D., Schöne, B., Milner, N., 2007. Sclerochronology and geochemical variation in limpet shells (Patella vulgata): a new archive to reconstruct coastal sea surface temperature. Geochem. Geophy. Geosys. 8(7), 1-17.

Ferguson, J.E., Henderson, G.H., Fa, D.A., Finlayson, J.C., Charnley, N.R., 2011. Increased seasonality in the Western Mediterranean during the last glacial from limpet shell geochemistry. Earth Planet. Sc. Lett. 308, 325-333. 
Freitas, P.S., Clarke, L.J., Kennedy, H., Richardon, C.A., Abrantes, F., 2006. Environmental and biological controls on elemental $(\mathrm{Mg} / \mathrm{Ca}, \mathrm{Sr} / \mathrm{Ca}$, and $\mathrm{Mn} / \mathrm{Ca})$ ratios in shells of the king scallop Pecten maximus. Geochim. Cosmochim. Ac. 70, 5119-5133.

Foster, P., Chacko, J., 1995. Minor and trace elements in the shell of Patella vulgata (L.). Mar. Environmen. Res. 40(1), 55-76.

Friedman, I., O’Neil, J.R., 1977. Compilation of stable isotope fractionation factors of geochemical interest, in Data of Geochemistry, edited by M. Fleischer, p. 1-12, U. S. Gov. Print. Off., Washington, D.C.

Füllenbach, C.S., Schöne, B.R., Mertz-Kraus, R., 2015. Strontium/lithium ratios in shells of Cerastoderma edule - A potential temperature proxy for brackish environments, Geophysical Research Abstracts, EGU General Assembly 17.

Gentry, D.K., Sosidan, S., Grossman, E.L., Rosenthal, Y., Hicks, D., Lear, C.H., 2006. Stable isotope and $\mathrm{Sr} / \mathrm{Ca}$ profiles from the marine gastropod Conus ermineous: Testing a multiproxy approach for inferring paleotemperature and paleosalinity. Palaios 23(4) 195209.

Gillikin, D. P., A. Lorrain, J. Navez, J. W. Taylor, L. André, E. Keppens, W. Baeyens, F. Dehairs, 2005. Strong biological controls on $\mathrm{Sr} / \mathrm{Ca}$ ratios in aragonitic marine bivalve shells. Geochem. Geophy. Geosys. 6, Q05009.

Gillikin, D. P. and F. Dehairs (2013). Uranium in aragonitic marine bivalve shells. Palaeogeography Palaeoclimatology Palaeoecology 373:60-65 
Gordillo, S., Rabassa, J., Coronato, A., 2008. Paleoecology and paleobiogeographic patterns of mid-Holocene molluscs from the Beagle Channel (southern Tierra del Fuego, Argentina). Rev. Geol. Chile 35(2), 321-333.

Gordillo, S., Brey, T., Beyer, K., and Lomovasky, B.J., 2015. Climatic and environmental changes during the middle to lateHolocene in southern South America: A sclerochronological approach using the bivalve Retrotapes exalbidus (Dillwyn) from the Beagle Channel. Quaternary International 337: 83-90.

Grossman, E.L., 2012. Applying oxygen isotope paleothermometry in deep time. In Reconstructing Earth's Deep-Time Climate-The State of the Art in 2012, Paleontological Society Short Course, November 3, 2012. The Paleontological Society Papers, Volume 18, Linda C. Ivany and Brian T. Huber (eds.), pp. 39-67.

Hall, J.M., and Chan, L.-H., 2004. Li/Ca in multiple species of benthic and planktonic foraminifera: thermocline, latitudinal and glacial-interglacial variation. Geochim. Cosmochim. Ac. 68(3), 529-545.

Hathorne, E.C., and James, R.H.., 2006. Temporal record of lithium in seawater: a tracer for silicate weathering? Earth and Planetary Science Letters, 246(3-4) pp. 393-406.

Hathorne, E.C., Felis, T., Suzuki, A., Kawahata, H., Cabioch, G., 2013. Lithium in the aragonite skeletons of massive Porites corals: A new tool to reconstruct tropical sea surface temperatures. Paleoceanography 28, 143-152.

Hickson, J.A., Johnson, A.L.A., Heaton, T.H.E., and Balson, P.S., 1999. The shell of the Queen Scallop Aequipecten opercularis (L.) as a promising tool for palaeoenvironmental 
reconstruction: evidence and reasons for equilibrium stable-isotope incorporation. Palaeogeography, Palaeoclimatology, Palaeoecology. 154(4), 325-337.

Jenkins, S.R., and Hartnoll, R.G., 2001. Food supply, grazing activity and growth rate in the limpet Patella vulgata L.: a comparison between exposed and sheltered shores. J. Exp. Mar. Biol. Ecol. 258(1), 123-139.

Kinsman, D. J. J., and H. D. Holland (1969), The co-precipitation of cations with $\mathrm{CaCO}_{3}$ - IV. The co-precipitation of $\mathrm{Sr} 2+$ with aragonite between $16^{\circ} \mathrm{C}$ and $96^{\circ} \mathrm{C}$, Geochim. Cosmochim. Acta, 33, 1-17.

Klein, R.T., Lohmann, K.C., Thayer, C.W., 1996. Bivalve skeletons record sea-surface temperature and $\delta^{18} \mathrm{O}$ via $\mathrm{Mg} / \mathrm{Ca}$ and ${ }^{18} \mathrm{O} /{ }^{16} \mathrm{O}$ ratios. Geology 24(5), 415-418.

Lazareth, C.E., Vander Putten, E., André, L., and Dehairs, F., 2003. High-resolution trace element profiles in shells of the mangrove bivalve Isognomon ephippium: a record of environmental spatio-temporal variations? Estuar. Coast. Shelf S. 57, 1103-1114.

Lorens, R. B. (1981). Sr, Cd, Mn and Co distribution coefficients in calcite as a function of calcite precipitation rate. Geochim. Cosmochim. Acta 45, 553-561.

Lorrain, A., Gillikin, D.P., Paulet, Y-M., Chauvaud, L., Mercier, A.L., et al., 2005. Strong kinetic effects on $\mathrm{Sr} / \mathrm{Ca}$ ratios in the calcitic bivalve. Geology, Geological Society of America, 33(12). 965-968.

Marriott, C.S., Henderson, G.M., Belshaw, N.S., Tudhope, A.W., 2004. Temperature dependence of $\delta^{7} \mathrm{Li}, \delta^{44} \mathrm{Ca}$ and $\mathrm{Li} / \mathrm{Ca}$ during growth of calcium carbonate. Earth Planet. Sci. Lett. 222, 615-624. 
Mouchi, V., de Rafélis, M., Lartaud, F., Fialin, M., Verrecchia, E., 2013. Chemical labelling of oyster shells used for time-calibrated high-resolution $\mathrm{Mg} / \mathrm{Ca}$ ratios: a tool for estimation of past seasonal temperature variations. Palaeogeogr. Palaeoclimatol. Palaeoecol. 373, $66-74$.

O’Neil, D.D., and D. P. Gillikin (2014). Do freshwater mussel shells record road salt pollution? Scientific Reports (Nature) 4:7168

Pearce, N.J.G , Perkins, W.T., Abell, I., Duller, G.A.T., Fuge, R., 1992. Mineral microanalysis by laser ablation inductively coupled plasma mass spectrometry. J. Anal. Atom. Spectrom. 7, 53-57

Poulain, C., Gillikin, D.P., Thébault, J., Munaron, J.M., Bohn, M., Robert, R., Paulet, Y.-M., Lorrain, A., 2015. An evaluation of $\mathrm{Mg} / \mathrm{Ca}, \mathrm{Sr} / \mathrm{Ca}$, and $\mathrm{Ba} / \mathrm{Ca}$ ratios as environmental proxies in aragonite bivalve shells. Chem. Geol. 396, 42-50.

Purton, L., Shields, G.A., Brasier, M.D., Grime, G.W., 1999. Metabolism controls Sr/Ca ratios in fossil aragonitic mollusks. Geology 27(12), 1083-1086.

Quinn, T.M., Taylor, F.W., Crowley, T.J., 2006. Coral-based climate variability in the Western Pacific Warm Pool since 1867. J. Geophys. Res. 111, 1-11.

Schifano, G., Censi, P., 1986. Oxygen and carbon isotope composition, magnesium and strontium contents of calcite from a subtidal Patella caerulea shell. Chem. Geol.: Isotope Geoscience Section 58(4), 325-331.

Shackleton, N.J., 1973, Oxygen isotope analysis as a means of determining season of occupation of prehistoric midden sites. Archaeometry 15(1): 133-141. 
Smith, S.V., Buddemeier, R.W., Redalje, R.C., Houck, J.E., 1979. Strontium-calcium thermometry in coral skeletons. Science 204(4931), 404-407.

Sosidan, S., Gentry, D.K., Lear, C.H., Grossman, E.L., Hicks, D., Rosenthal, Y., 2006. Strontium to calcium ratios in the marine gastropod Conus ermineous: Growth rate effects and temperature calibration. Geochem. Geophy. Geosys. 7(11), 1-17.

Surge, D. and Barrett, J.H. (2012) Marine climatic seasonality during medieval times (10th to 12th centuries) based on isotopic records of Viking Age shells from Orkney, Scotland. Palaeogeography, Palaeoclimatology, Paleoecology, 350-352(0): 236-246, doi: 10.1016/j.palaeo.2012.07.003.

Surge, D. and Lohmann, K. C, 2008. Evaluating $\mathrm{Mg} / \mathrm{Ca}$ ratios as a temperature proxy in the estuarine oyster, Crassostrea virginica. Journal of Geophysical Research: Biogeosciences, 113, G02001, doi:10.1029/2007JG000623.

Surge, D. and Walker, K. J. (2006). Geochemical variation in microstructural shell layers of the southern quahog (Mercenaria campechiensis): implications for reconstructing seasonality. Palaeogeography, Palaeoclimatology, Palaeoecology, 237(2-4):182-190.

Surge, D., Wang, T., Gutiérrez-Zugasti, I., Kelley, P. H., 2013. Isotope sclerochronology and season of annual growth line formation in limpet shells (Patella vulgata) from warm- and cold-temperate zones in the eastern North Atlantic. Palaios 28, 386-393, doi: 10.2110/palo.2012.p12-038r. 
Takesue, R.K., van Geen, A., 2004. Mg/Ca, Sr/Ca, and stable isotopes in modern and Holocene Protothaca staminea shells from a northern California coastal upwelling region. Geochim. Cosmochim. Ac. 68(19), 3845-3861.

Tesoriero, A. J., and J. F. Pankow (1996), Solid solution partitioning of $\mathrm{Sr}^{2+}, \mathrm{Ba}^{2+}$, and $\mathrm{Cd}^{2+}$ to calcite, Geochim. Cosmochim. Acta, 60, 1053-1063.

Thébault, J., B. R. Schöne, N. Hallmann, M. Barth, and E. V. Nunn (2009), Investigation of $\mathrm{Li} / \mathrm{Ca}$ variations in aragonitic shells of the ocean quahog Arctica islandica, northeast Iceland, Geochem. Geophys. Geosyst., 10, Q12008.

Thébault, J., and Chauvaud, L., 2013. Li/Ca enrichments in great scallop shells (Pecten maximus) and their relationship with phytoplankton blooms. Palaeogeography, Palaeoclimatology, Palaeoecology, 373, 108-122.

Vander Putten, E., Dehairs, F., Keppens, E., Baeyens, W., 2000. High resolution distribution of trace elements in the calcite shell layer of modern Mytilus edulis: Environmental and biological controls. Geochim. Cosmochim. Ac. 64(6), 997-1011.

Wanamaker, A.D., Jr., Kreutz, K.J., Wilson, T., Borns, H.W., Jr., Introne, D.S., and Feindel, S., (2008), Experimentally determined $\mathrm{Mg} / \mathrm{Ca}$ and $\mathrm{Sr} / \mathrm{Ca}$ ratios in juvenile bivalve calcite for Mytilus edulis: Implications for paleotemperature reconstructions, Geo-Marine Letters, Special Issue, Advances in mollusc sclerochronology and sclerochemistry: tools for understanding climate and environment, 28.

Wang, T., Surge, D., Mithen, S., 2012. Seasonal temperature variability of the Neoglacial (33002500 BP) and Roman Warm Period (2500-1600 BP) reconstructed from the oxygen 
isotope ratios of limpets shells (Patella vulgata), Northwest Scotland. Palaeogeography, Palaeoclimatology, Palaeoecolgy. 317-318, 104-113.

Wisshak, M., Correa, M.L, Gofas, S., Salas, C., Taviani, M., Jakobsen, J., Freidwald, A., 2008. Shell architecture, element composition, and stable isotope signature of the giant deepsea oyster Neopycnodonte zibrowii sp. N. from the NE Atlantic. Deep-Sea Res. PT I 56, $374-407$. 
Table 1.

\begin{tabular}{|c|c|c|c|c|c|c|c|c|c|c|c|c|c|}
\hline ShellName & $\begin{array}{l}\text { Age } \\
\text { (yri) }\end{array}$ & $\begin{array}{l}\text { Leagth } \\
\text { rampled } \\
\text { (mm) }\end{array}$ & $\begin{array}{l}\text { Mean } \\
\text { extension } \\
\text { rate } \\
\text { (mmyr) }\end{array}$ & $\begin{array}{l}\text { Min } \\
{ }^{217} \mathrm{O}\end{array}$ & $\frac{M a x}{b^{t 1} 0}$ & $\begin{array}{c}\Delta^{3} \mathrm{O} \\
\text { (atax-Mtin) }\end{array}$ & $\begin{array}{l}\text { Average } \\
\text { o" }^{110}\end{array}$ & $\frac{S D}{b^{11} O}$ & $\frac{\text { Min }}{{ }_{0}^{2} \mathrm{C}}$ & $\begin{array}{l}\mathrm{Mas} \\
6^{4} \mathrm{C}\end{array}$ & $\begin{array}{c}\Delta^{4} \mathrm{C} \\
\text { (Max-Mia) }\end{array}$ & $\begin{array}{c}\text { Average } \\
b^{14} \mathrm{C}\end{array}$ & $\underset{b^{2} \mathrm{C}}{\mathrm{SD}}$ \\
\hline \multicolumn{14}{|l|}{ Nencastle, UK } \\
\hline $\begin{array}{l}\text { Pavelild (NI, 0601-3) } \\
\text { Orianey, UK }\end{array}$ & 6 & 10,7 & 1.8 & 0.5 & 3.4 & 2.8 & 20 & 0.7 & -1.5 & 0.5 & 2 & -02 & 0.4 \\
\hline $\begin{array}{l}\text { Patilla (ORK, ITS) } \\
\text { Tierra del Fuego, AR }\end{array}$ & 5 & 117 & 2.3 & 02 & 3.4 & 32 & 25 & 0.6 & -0.6 & 0.5 & 1.4 & 0.1 & 03 \\
\hline Nacella (ND.ARCH-1) & 0.5 & 5.5 & 11.0 & 02 & 2 & 18 & 1.4 & 0.5 & 2.1 & 26 & 0.5 & 2.4 & 0.1 \\
\hline Narnila (ND-ARCH-3) & 1.5 & 83 & 5,5 & 02 & 2.5 & 23 & 12 & 0.7 & 1.1 & 24 & 1.3 & 1.8 & 0.4 \\
\hline Naxella (ND-MOD-I) & 4 & is & 3.8 & 0.7 & 3.8 & 31 & 1.9 & 0.6 & 12 & 2.3 & 11 & 1.7 & 03 \\
\hline Niarella (ND MOD-6) & 2.5 & 7.5 & 3.0 & 0.7 & 2.8 & 21 & 1,8 & 06 & 0.7 & 19 & 12 & 15 & 0.4 \\
\hline
\end{tabular}


Table 2

\begin{tabular}{|c|c|c|}
\hline Date & $\delta^{11} \mathrm{O}_{\text {matre }}\left(\mathrm{S}_{6}\right)$ & Reference \\
\hline Dec-09 & -13 & Colonese et al (2012) \\
\hline $\operatorname{Jan}-10$ & -1.6 & Colonese et al (2012) \\
\hline Feb-10 & -1.4 & Colonese et al (2012) \\
\hline Apr-10 & -12 & Colonese et al (2012) \\
\hline $\operatorname{Jun}-10$ & -13 & Colonese et al (2012) \\
\hline Ang-10 & -0.8 & Colonese et al (2012) \\
\hline Oct-10 & -1.2 & Colonese et al (2012) \\
\hline Oct-15: & -1.3 & This study \\
\hline Nov-15 & -1.5 & This study \\
\hline Dec-15 & -1.4 & This study \\
\hline $\operatorname{Tan}-16$ & -12 & This study \\
\hline Feb-16 & $-1,4$ & This study \\
\hline Mar-16 & -12 & This study \\
\hline Average & -1.3 & All data \\
\hline $\begin{array}{l}\text { Standard } \\
\text { deviation }\end{array}$ & 0.2 & All data \\
\hline
\end{tabular}




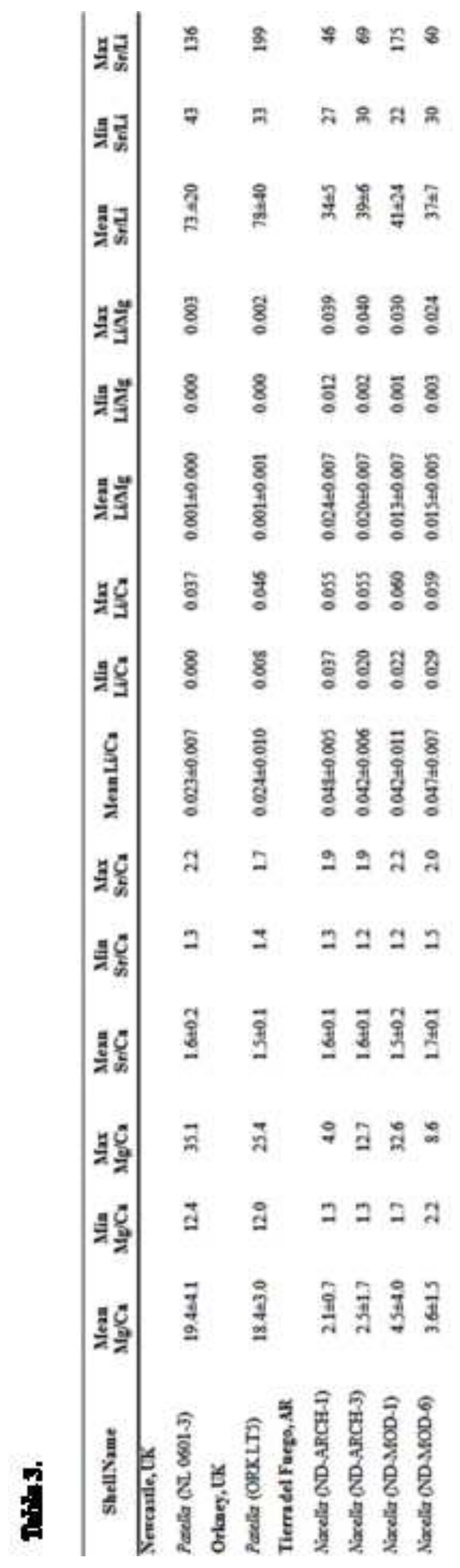




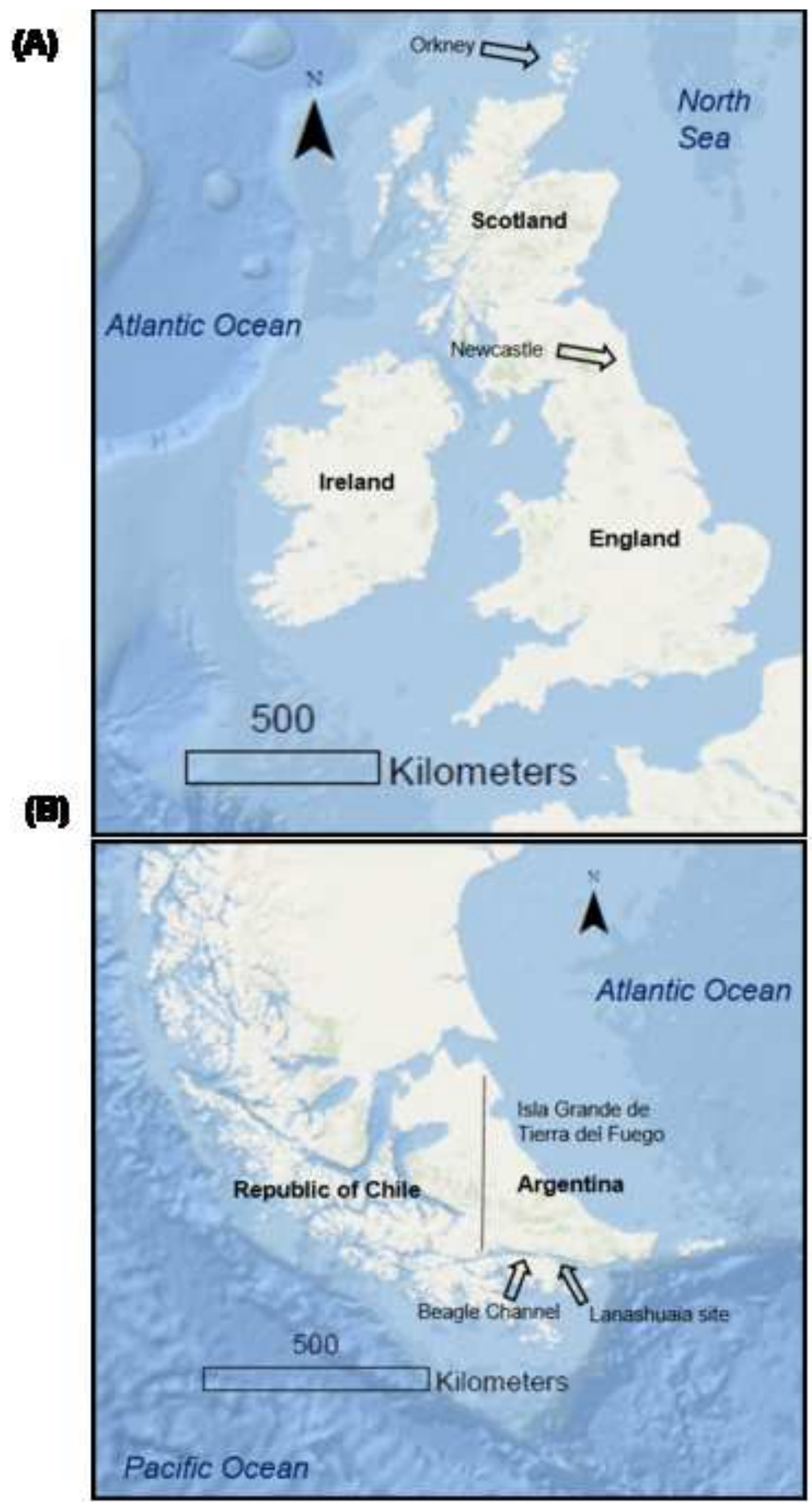

Figue 1

Figure 1 


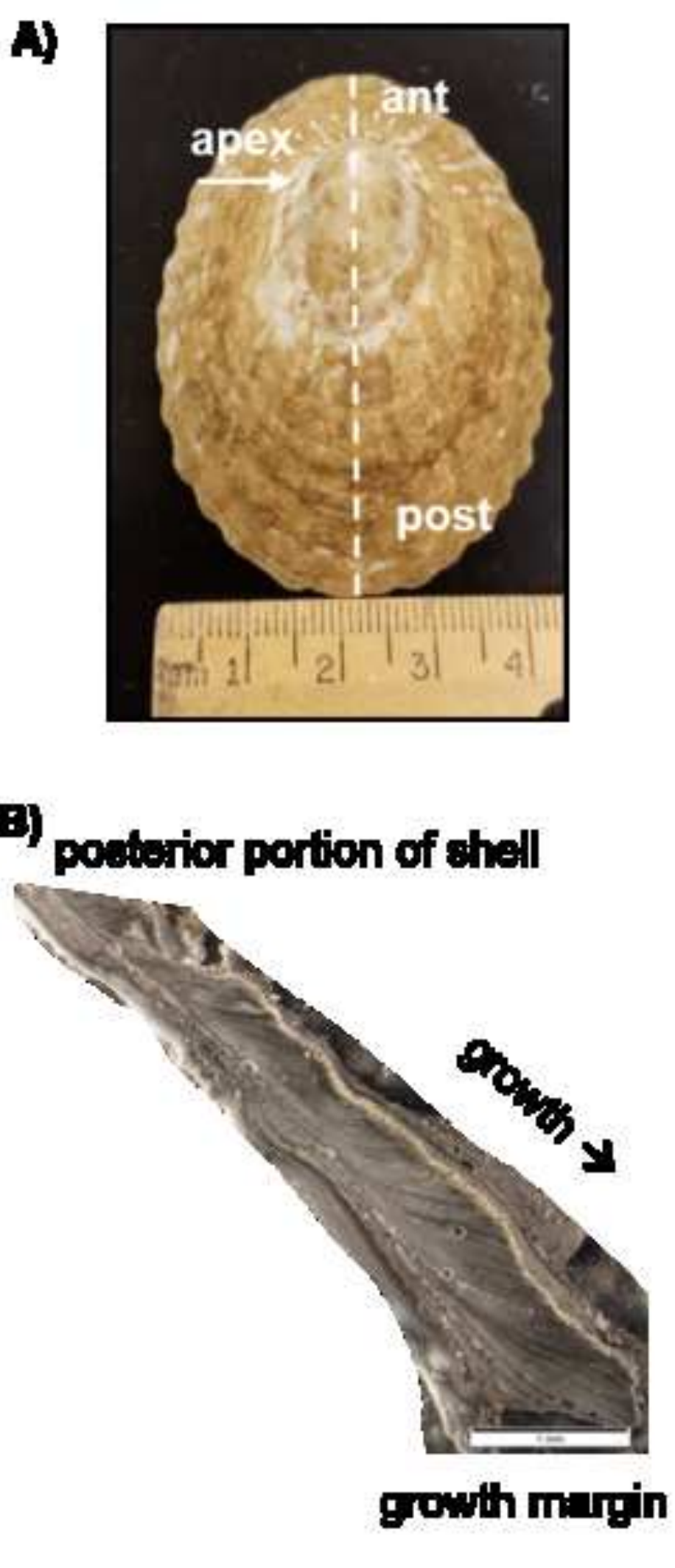

B)

posterior portion of shell

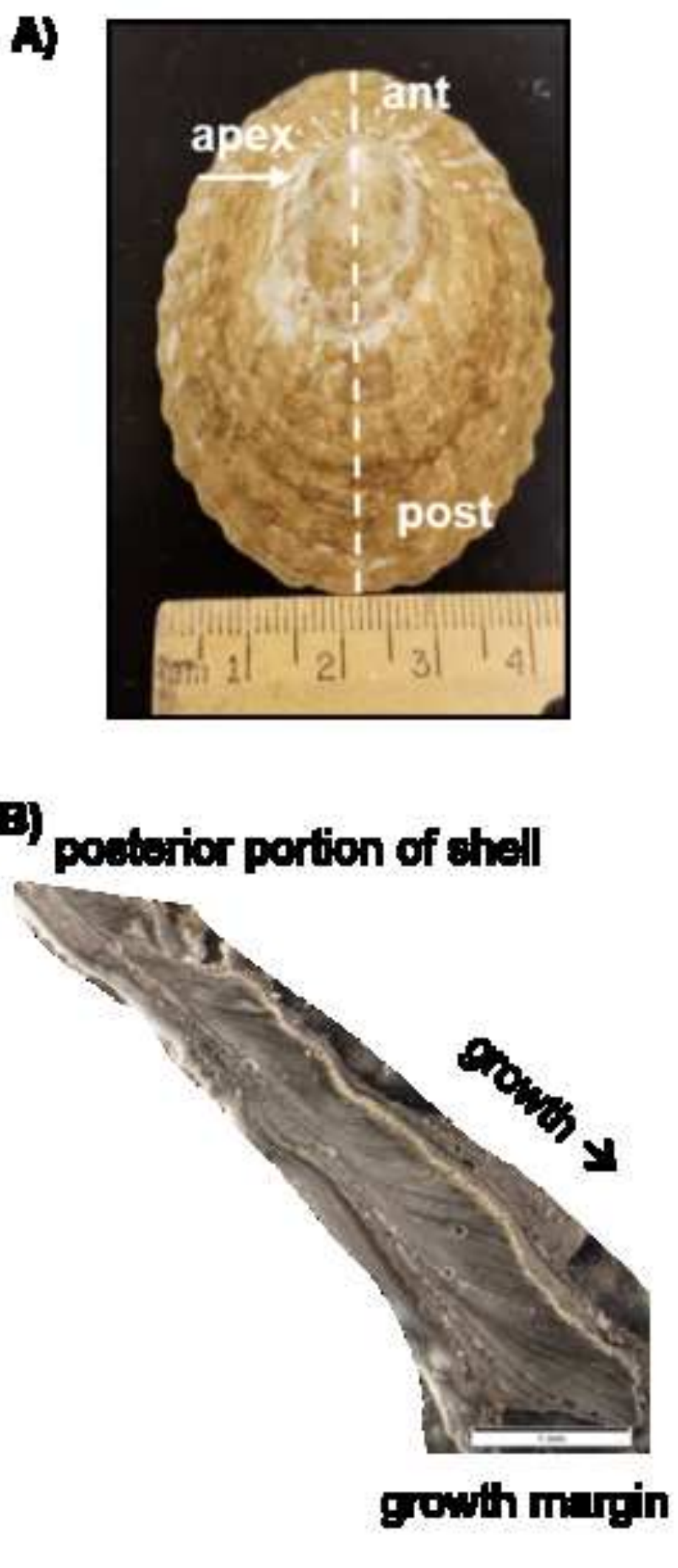

Fgure 2

Figure 2

\section{A)}

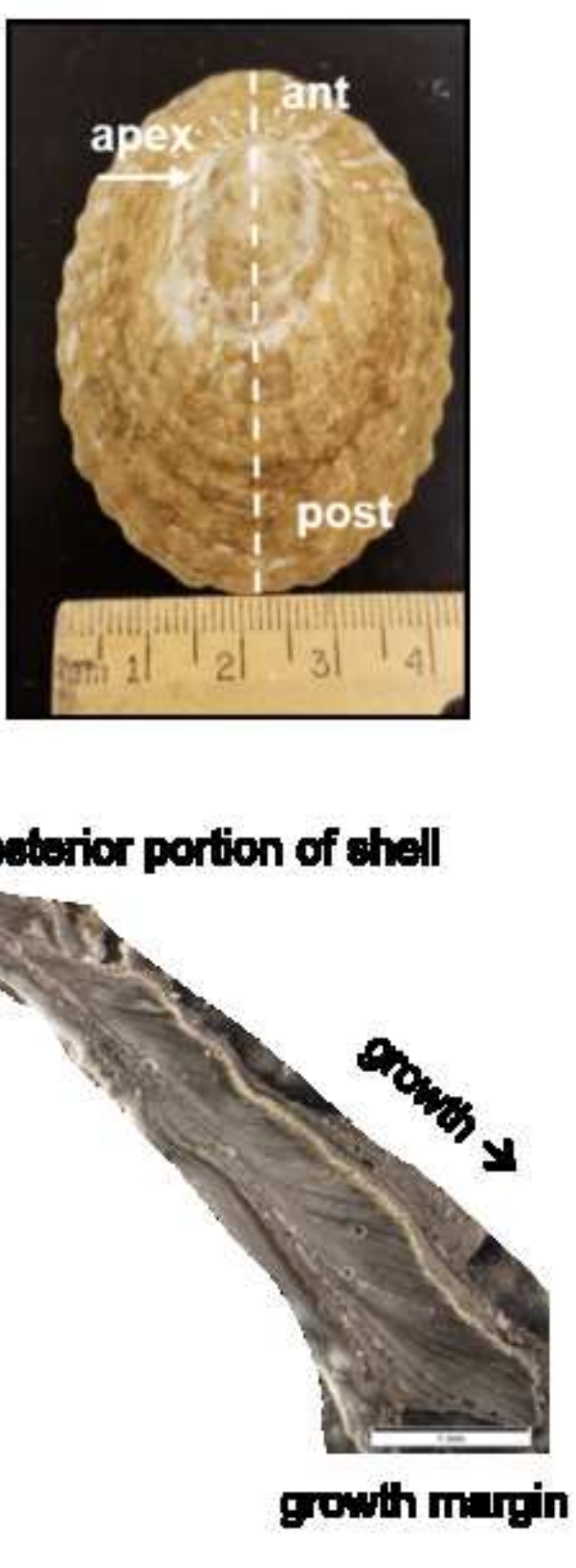

\section{gowth mingin}

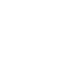

Figure 2
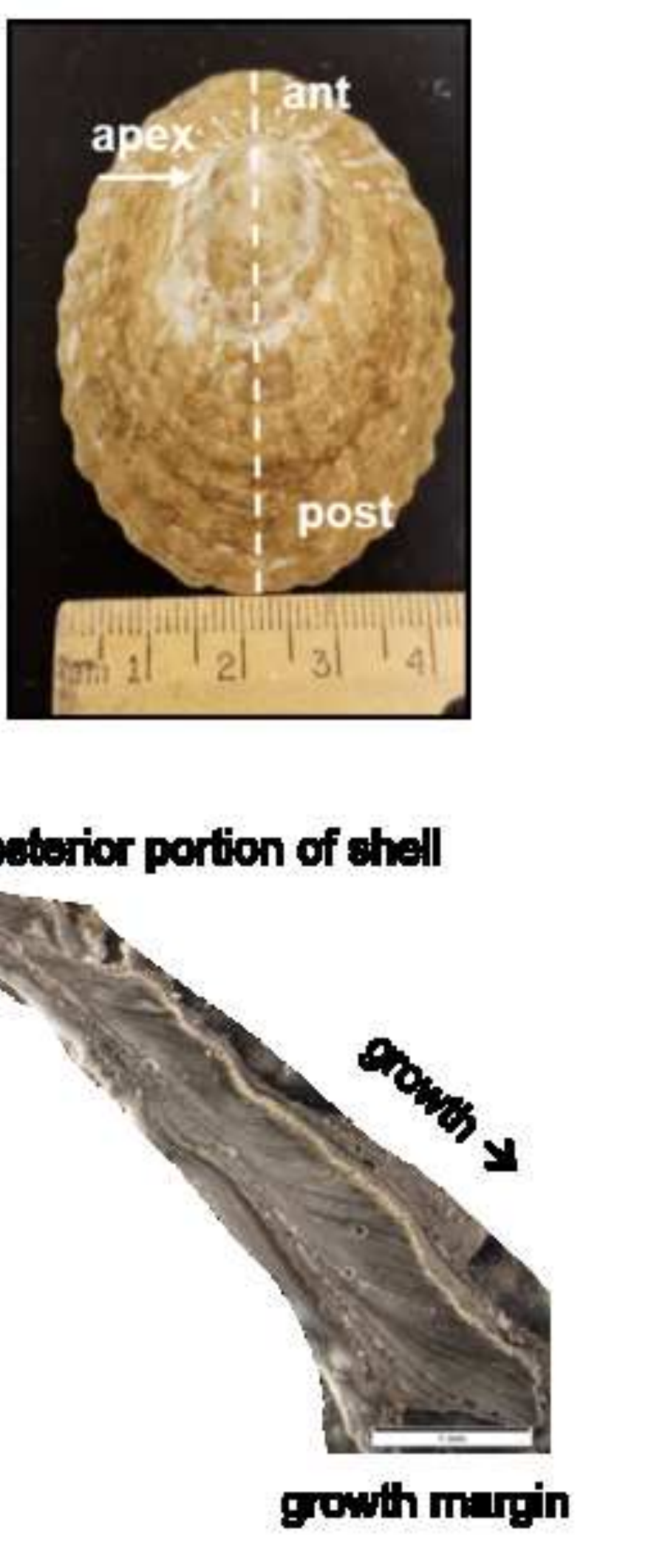

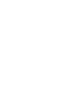

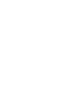

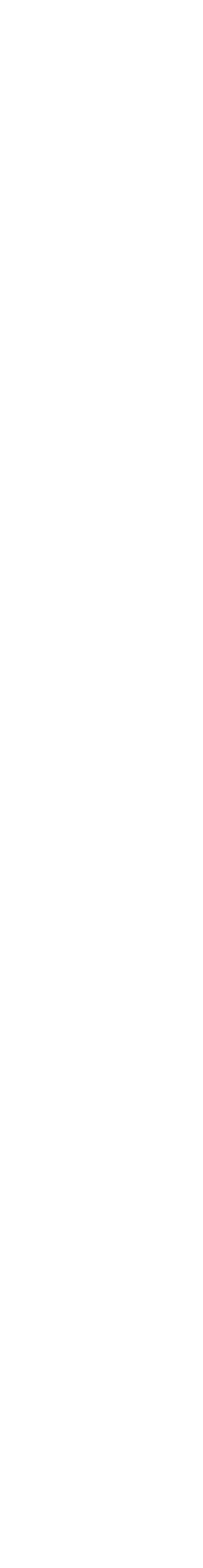



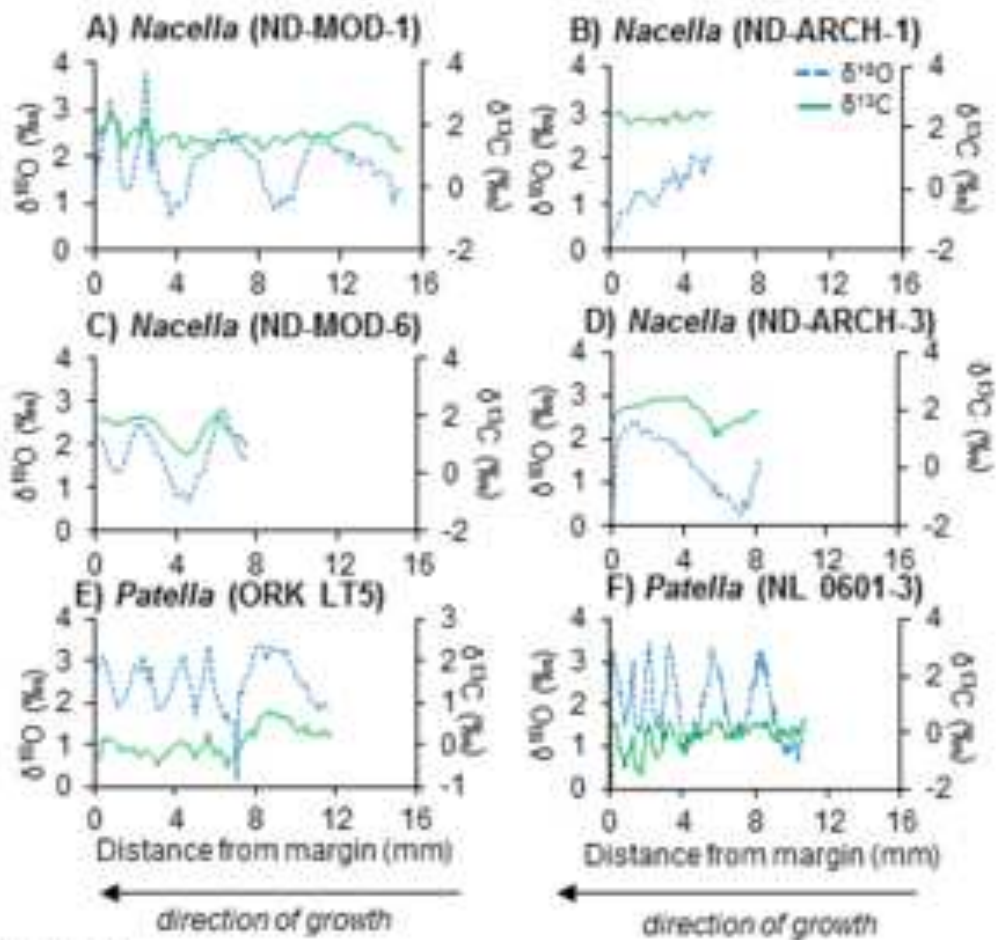

Figure 3 

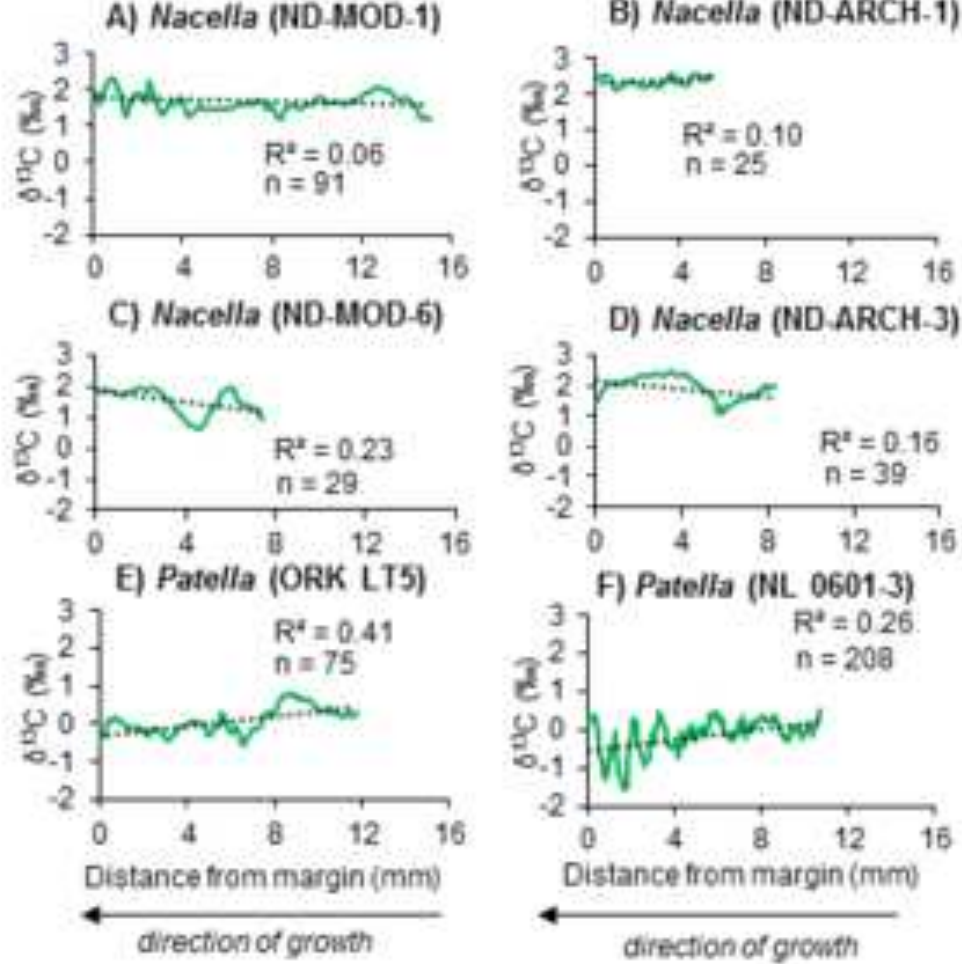

Figure 4 


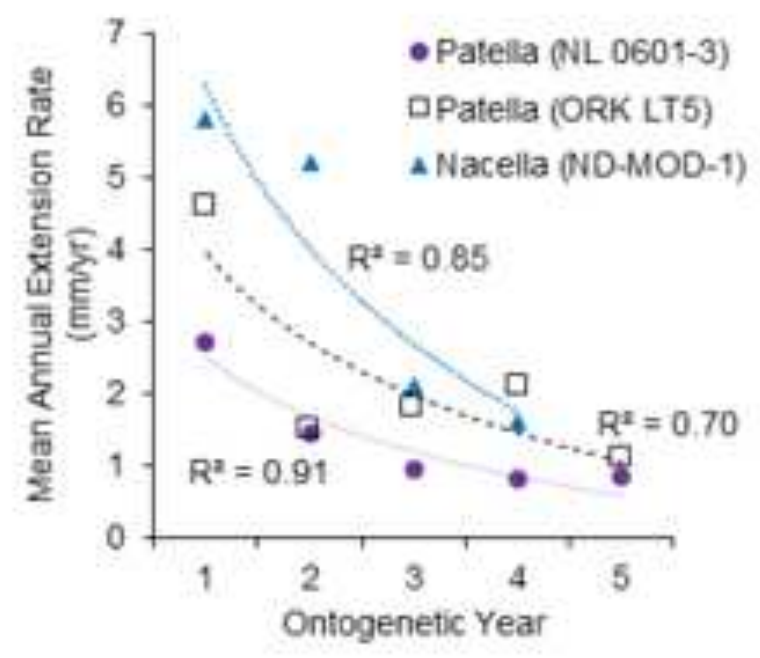

Figure 5

Figure 5

Figure 5 
Figure 6
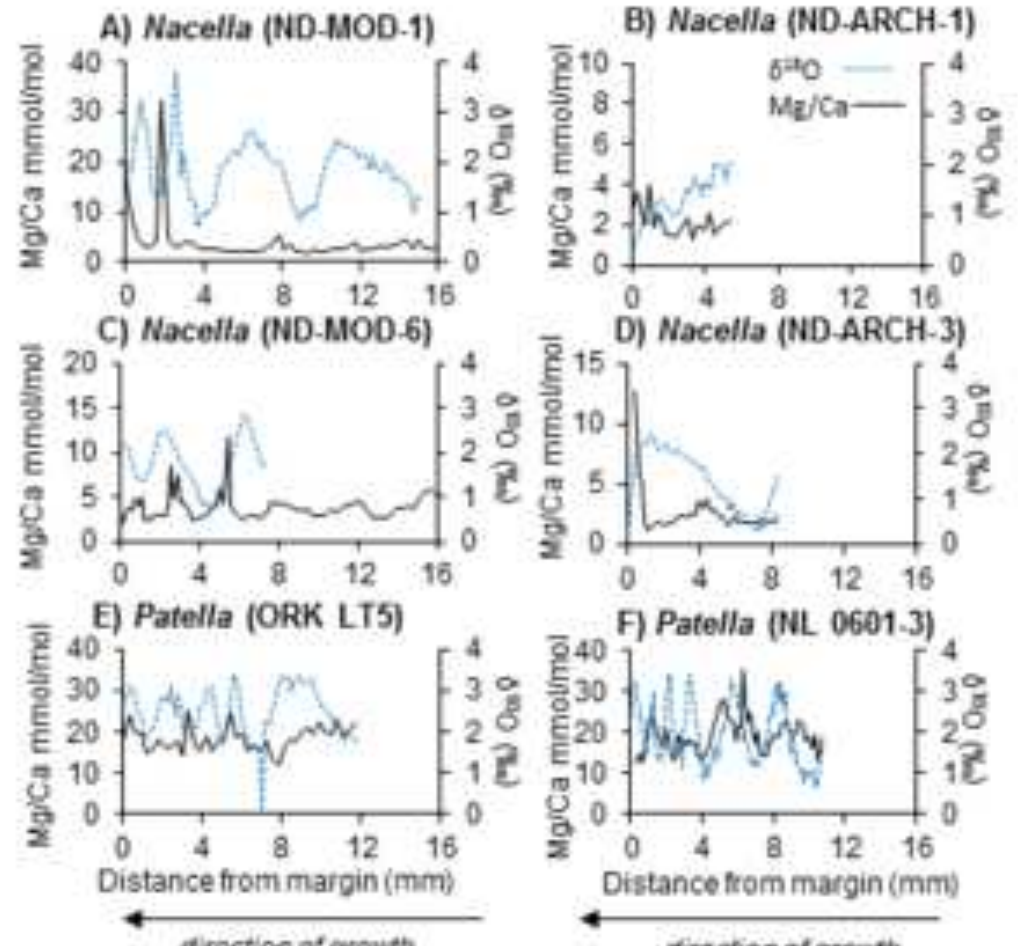

F) Patella (VIL 0601-3)

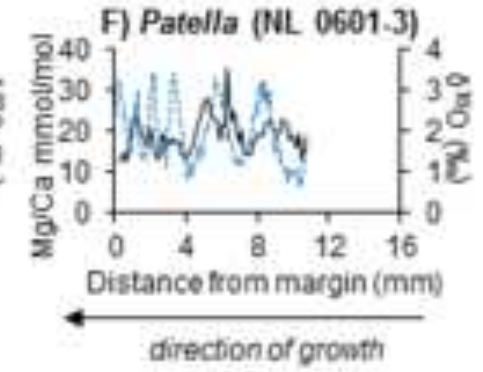

Figure 6 

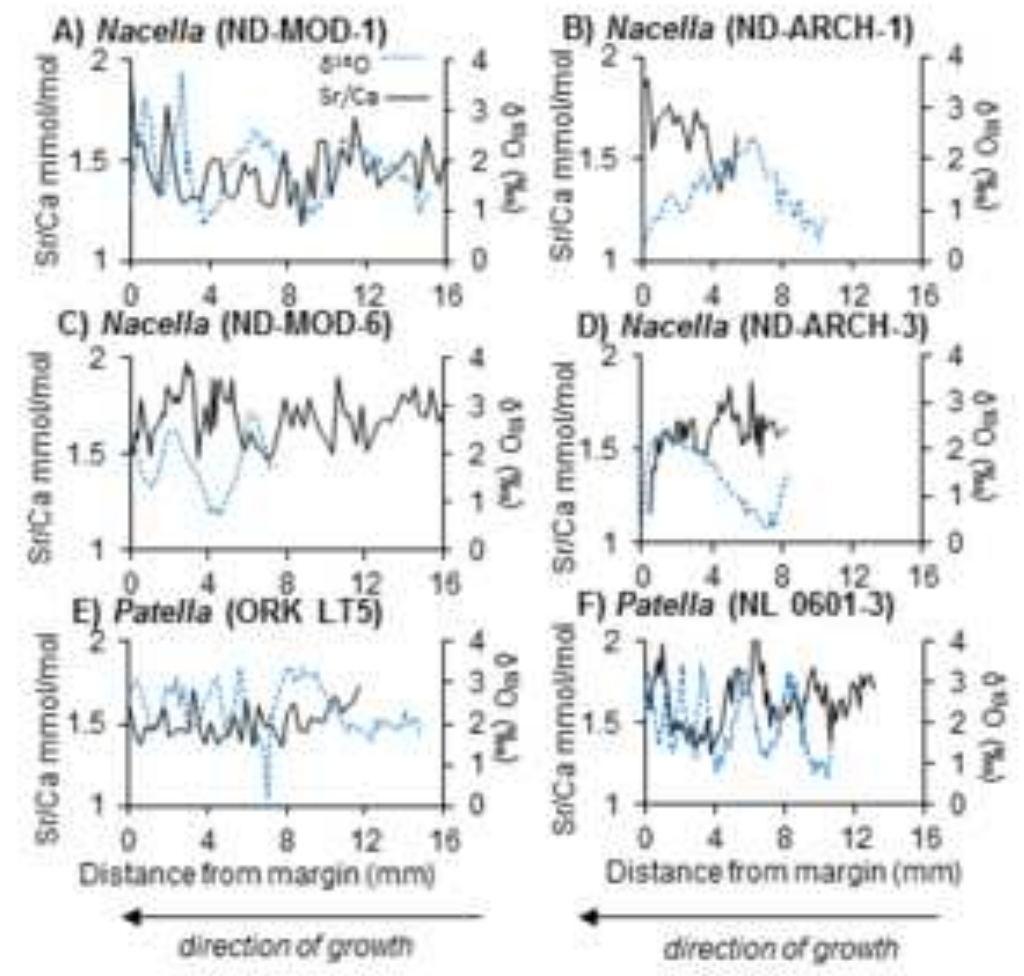

Figure 7 
Figure 8
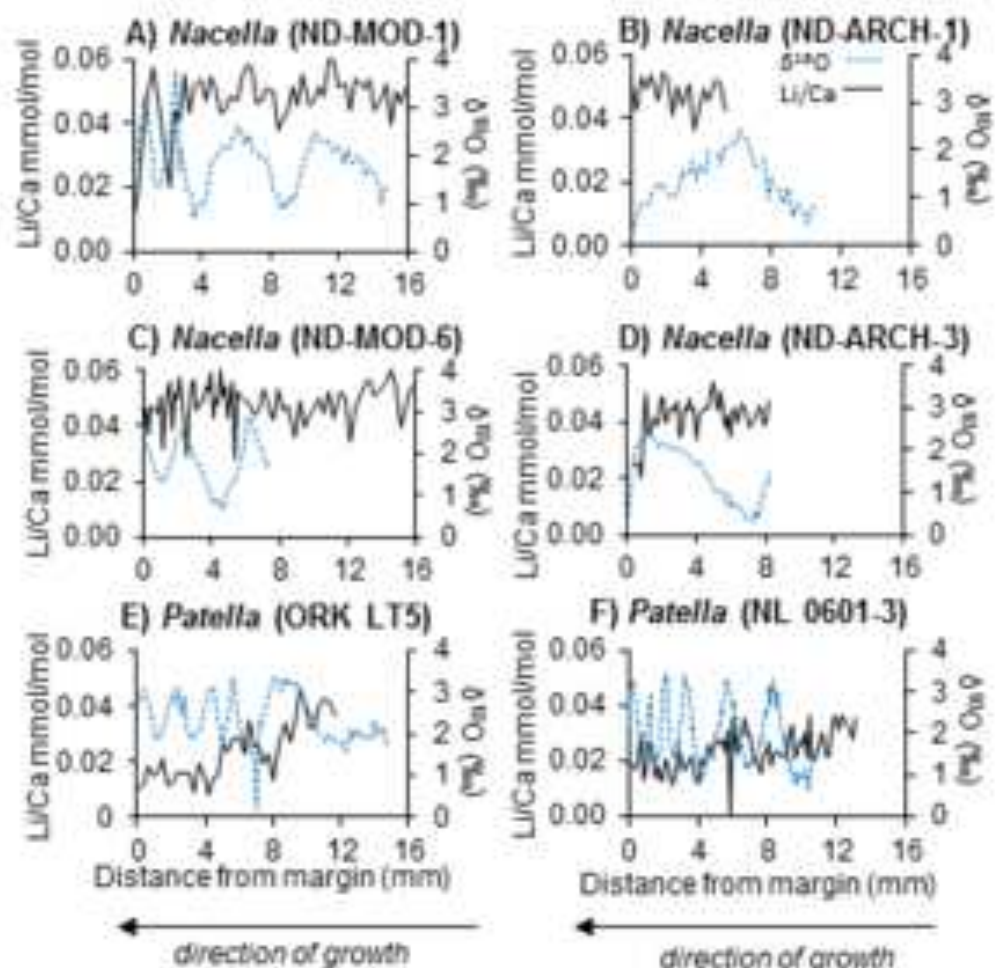

Figure 8

F) Patella (NL 0601-3)

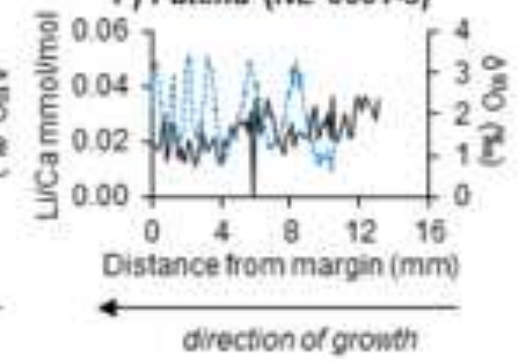

direction of growth 
Figure 9
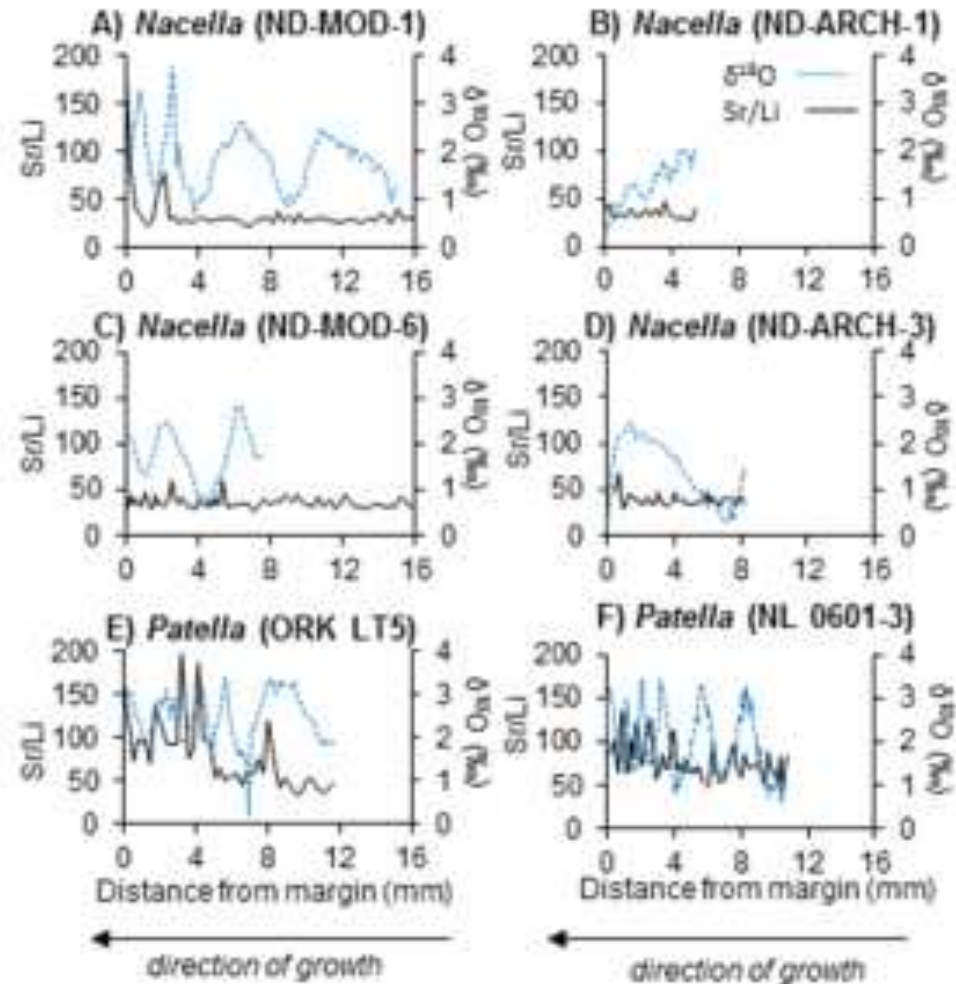

F) Patella (NL 0601-3)

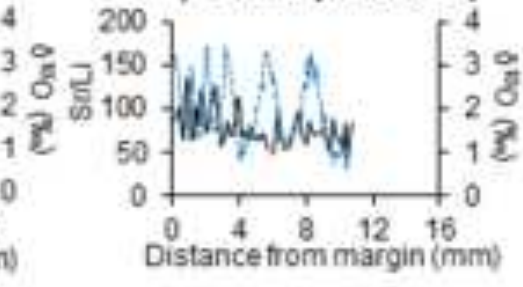

drection of growen

direction of growth

Figure 9 

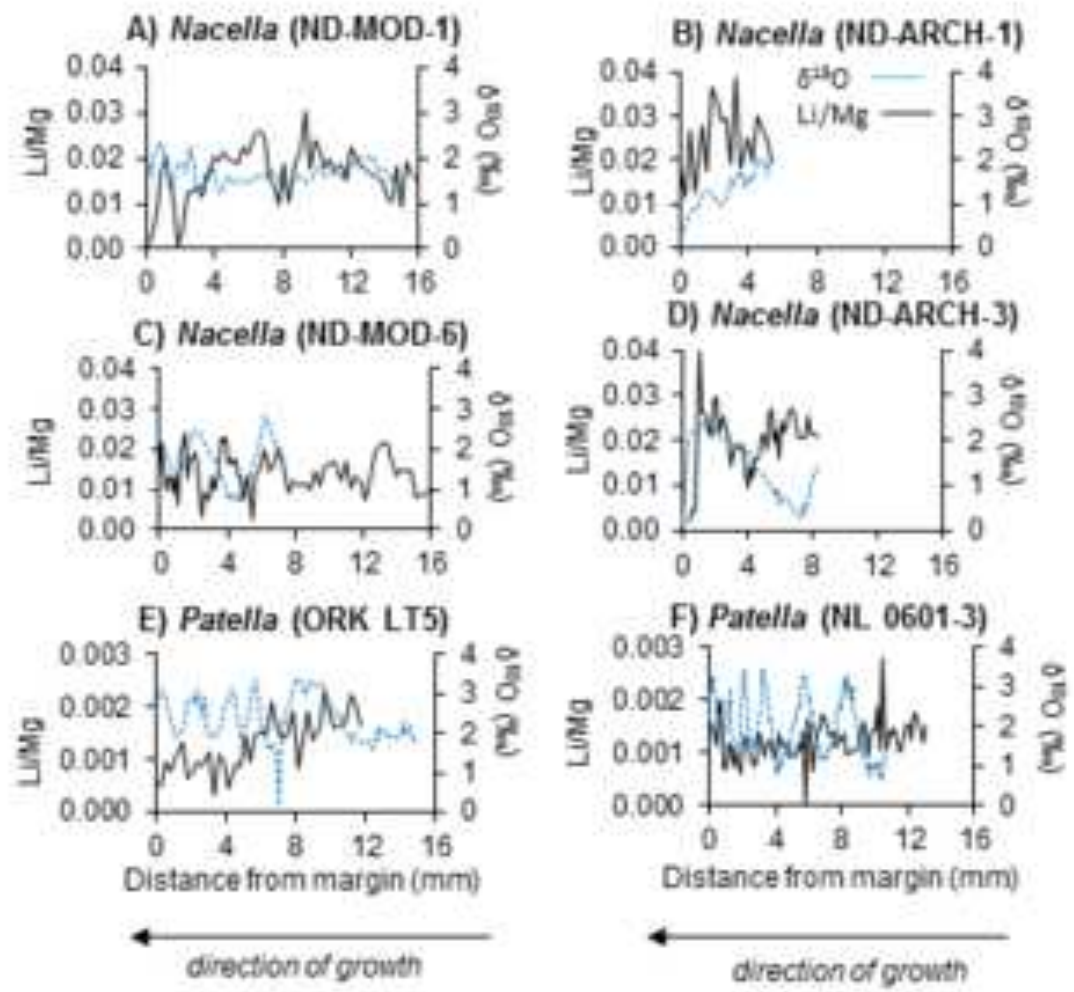

Figure 10 
Figure 11
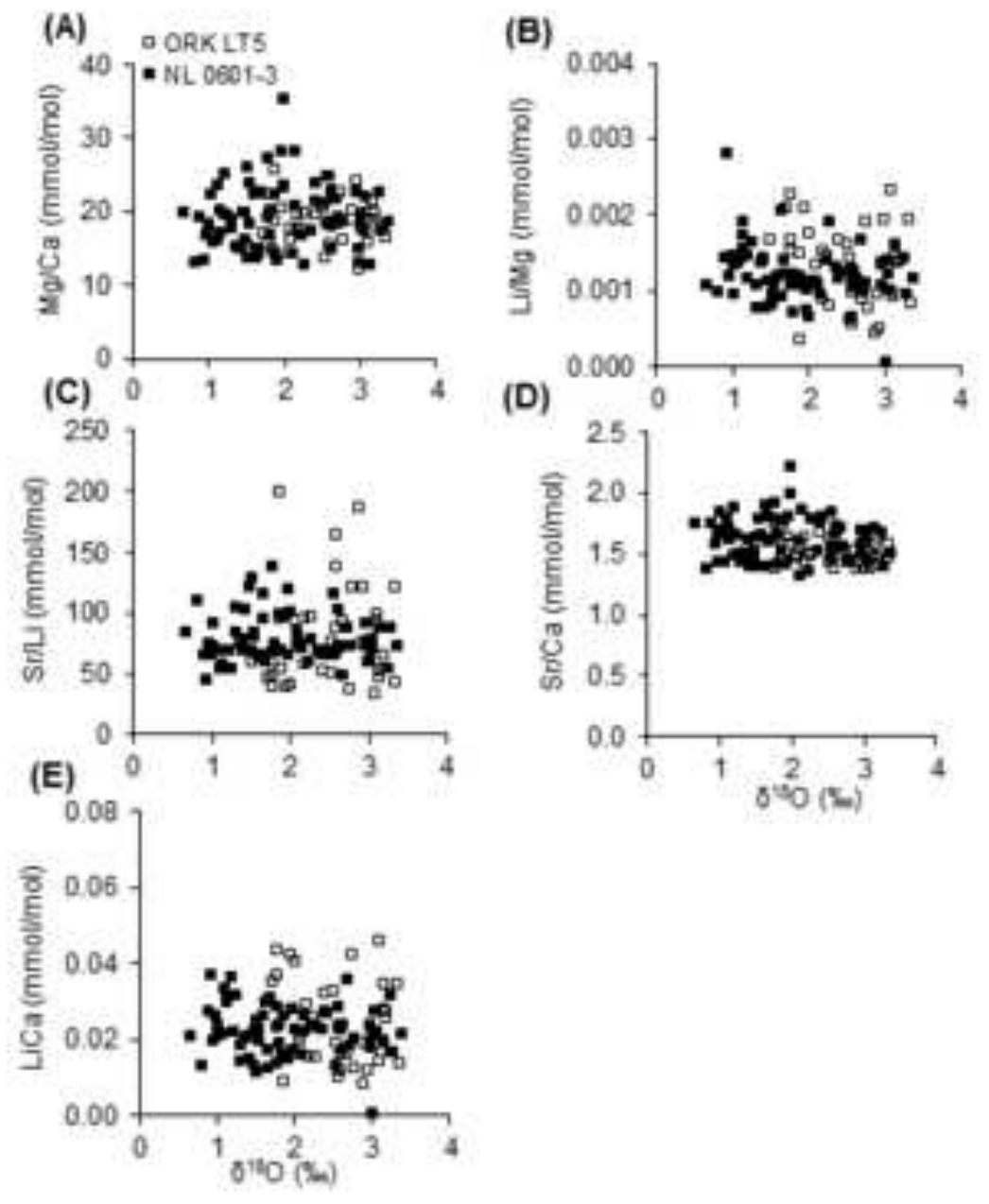

Figure 11A-E 
Figure 12

(A)
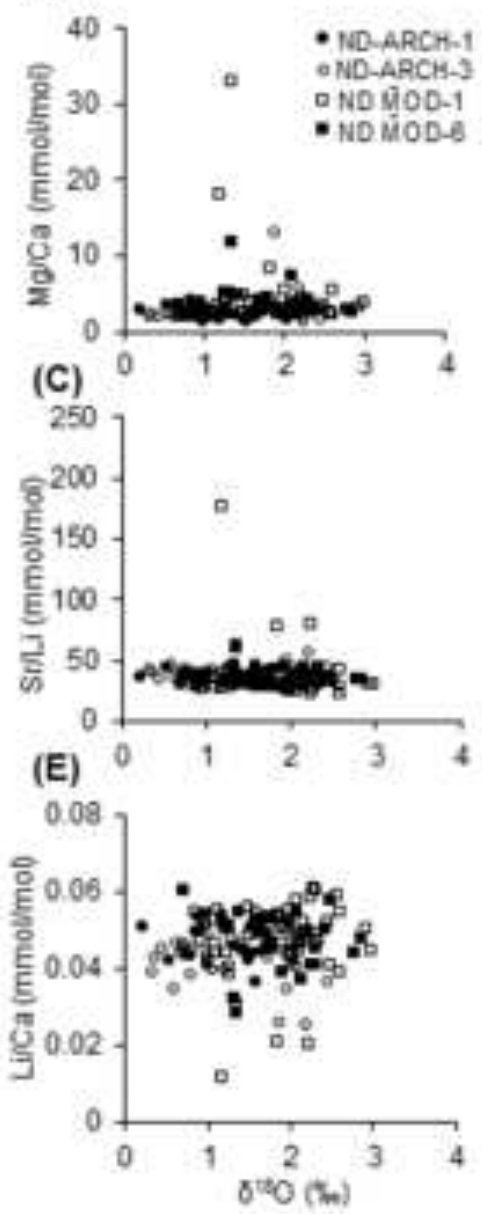

(B)

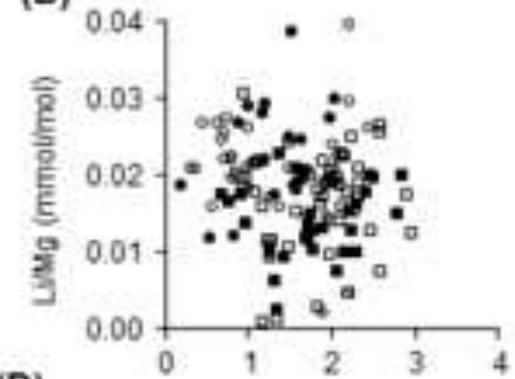

(D)

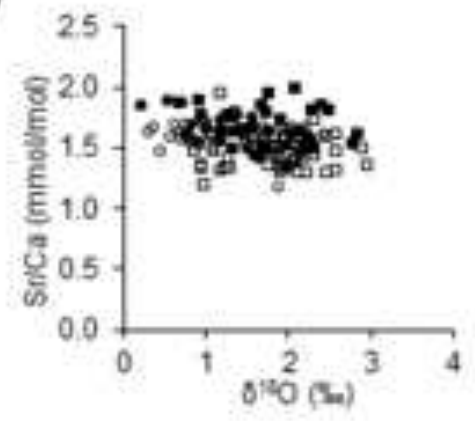

Figure 12A-E 
